\title{
In situ Sr isotope analysis of mantle carbonates: constraints on the evolution and sources of metasomatic carbon-bearing fluids in a paleo-collisional setting
}

Giulia Consuma $^{\mathrm{a}}$, Roberto Braga ${ }^{\mathrm{a},{ }^{*}}$, Tommaso Giovanardi ${ }^{\mathrm{b}}$, Danilo Bersani ${ }^{\mathrm{c}}$, Jürgen Konzett ${ }^{\mathrm{d}}$, Federico Lugli ${ }^{\mathrm{e}}$, Maurizio Mazzucchelli ${ }^{\mathrm{b}}$, Peter Tropper $^{\mathrm{d}}$

${ }^{a}$ Department of Biological, Geological and Environmental Sciences, University of Bologna, Piazza di Porta San Donato 1, 40126 Bologna, Italy

${ }^{\mathrm{b}}$ Department of Chemical and Geological Sciences, University of Modena and Reggio Emilia, Via Campi 103, 41125 Modena, Italy

${ }^{\mathrm{c}}$ Department of Mathematical, Physical and Computer Sciences, University of Parma, Parco Area delle Scienze 7/A, 43124, Parma, Italy

${ }^{\mathrm{d}}$ Institute of Mineralogy and Petrology, University of Innsbruck, Innrain52, 6020 Innsbruck, Austria

${ }^{\mathrm{e}}$ Department of Cultural Heritage, University of Bologna, Via degli Ariani 1, 48100 Ravenna, Italy

*Corresponding author: r.braga@unibo.it (Roberto Braga)

\section{ABSTRACT}

1 Carbonate-bearing wedge peridotites attest the mobilization of carbon (C) by slab fluids/melts

2 circulating in a subduction setting. In general, $\mathrm{COH}$ fluids are thought to derive from the

3 dehydration/partial melting of the crustal portions of slabs, especially during the exhumation of

4 crust-mantle mélanges along continental subduction channels. In this study we combined textural observations with in-situ $\mathrm{Sr}$ isotope analyses of mantle carbonates occurring in different microstructural sites to test whether the fluids responsible for the carbonation of a mantle wedge derived from the subducted continental crust or not. We focus on the Ulten Zone peridotites (Eastern Italian Alps) associated with high-grade felsic rocks, where carbonates occur mainly as

9 dolomite and minor magnesite and calcite. Analyses by a laser ablation system coupled to a 10 Neptune MC-ICP-MS on peridotites representing different episodes of a complex metasomatic

11 history, indicate that $\mathrm{Sr}$ isotopic variations can be linked to the different microstructural positions of 12 carbonates. The C-metasomatism of UZ peridotites can be outlined in two stages. The first stage is 13 the $H P$-carbonation at peak (eclogite-facies) conditions, with formation of interstitial matrix 14 dolomite in textural equilibrium with hornblende to pargasite amphibole and Cl-apatite. This 
15 dolomite exhibits relatively unradiogenic ${ }^{87} \mathrm{Sr} /{ }^{86} \mathrm{Sr}$ present day values of $0.70487 \pm 0.00010$, requiring different sources with respect to the associated migmatites and the overhanging mantle wedge. Carbonation continued during exhumation, with local injection of C-rich fluids forming dolomite veins in association with tremolite and chlorite. The dolomite vein shows a wide range of ${ }^{87} \mathrm{Sr} /{ }^{86} \mathrm{Sr}(0.7036-0.7083)$, reflecting both the primary composition of carbonates and the consequent interaction with crustal fluids as expected in a crust-mantle mélange. The second stage is Cremobilization during the final exhumation by dolomite dissolution and precipitation of brucite intergrowths with calcite, that exhibits a quite similar Sr composition of the precursor dolomite.

The mantle wedge is therefore capable to store carbonates representing a complex metasomatic evolution from eclogite-facies conditions to very shallow structural levels. Fluids released from subducting slabs of continental lithosphere might be responsible for the crystallization, in the overlying ultramafic rocks, of metasomatic minerals such as amphibole, phlogopite and zircon, but their role on the carbonation of mantle wedge is most likely overestimated. The combination of geochemical, isotopic and textural evidence suggests the contribution of a distinct source of Cbearing fluids for included and interstitial dolomite, which could be related to depleted mantle wedge sources and/or trondhjemitic igneous activity. Differently, residual $\mathrm{COH}$-fluids released by the associated stromatic gneisses and orthogneisses acted during the end of exhumation, providing the highest $\mathrm{Sr}$ isotope values for the dolomite veins.

Keywords: Carbon Cycle; peridotite; mantle-wedge; In situ Sr isotope; metasomatism; Ulten Zone

\section{Introduction}

At convergent plate boundaries, the interface between subducting slab and overhanging mantle wedge represents a complex region, where a mix of slab- and wedge-derived lithologies plays a key role in the surface-to-mantle volatiles budget on Earth (Bebout and Penniston-Dorland, 2016). In this tectonic setting, the subduction of carbon (C) stored in organic matter and carbonate minerals is 
partly returned to the surface by slab fluids (Manning, 2014). The occurrence of hydrous and carbonated phases, and the enrichment in incompatible elements of the lithospheric mantle wedge above a subducting slab, testify the fluid-mediated large-scale cycling of elements. The $\mathrm{C}$ transfer among different reservoirs is usually related to fluids or melts expelled from the crustal portion of the subducted oceanic lithosphere (carbonated serpentinite, altered crust and sediments). However, many of the studied mantle wedge peridotites are now exposed within variable migmatized felsic gneisses, as a result of continental collision (Brueckner and Medaris, 2000; Zheng, 2012 and references therein). Accordingly, several studies highlight the importance of subducted continental crust as source of metasomatic C-bearing fluids/hydrous melts reacting and enriching the overhanging mantle wedge (Zanetti et al., 1999; Zheng, 2009; Hermann et al., 2013). An appropriate identification of the $\mathrm{C}$ sources during interactions between mantle wedge and subducted continental lithosphere is therefore essential in order to develop a quantitative understanding of the global C flux.

In this study we take advantage of the wealth of data already available on the multiple metasomatic history of the Ulten Zone (UZ) peridotite (northern Italy) to illustrate the formation and the dissolution-reprecipitation of carbonates at relatively shallow $(P<3 \mathrm{GPa})$ and cold $\left(T<850^{\circ} \mathrm{C}\right)$ conditions. The UZ peridotites record the transition from mantle wedge, coarse-grained, spinelperidotite to high-pressure, fine-grained, garnet-bearing amphibole-peridotite and, finally to low- $P$, low- $T$ serpentinized peridotites (Förster et al., 2017; Ionov et al., 2017; Gudelius et al., 2018). Therefore, these rocks offer the opportunity to investigate fluid-driven carbonation at different $P-T$ conditions, along the complex metasomatic evolution of a paleo-mantle wedge involved in continental collision. We combined microstructural observations, major elements compositions, micro-Raman analyses of carbonates and associated minerals, with in situ ${ }^{87} \mathrm{Sr} /{ }^{86} \mathrm{Sr}$ isotopic composition of carbonates as a tracer for investigating the potential sources of C-bearing fluids. The choice of using elemental $\mathrm{Sr}$ and ${ }^{87} \mathrm{Sr} /{ }^{86} \mathrm{Sr}$ ratio to shed more light on C-metasomatism is based on 
the fact that: (i) it is relatively abundant in the carbonates structure due to its easy substitution with $\mathrm{Ca}^{2+}$; (ii) the partition of $\mathrm{Rb}$ into the carbonate crystal structure is hampered because of its large ionic size, and we therefore assume that carbonates may inherit the $\mathrm{Sr}$ isotopic composition of Cbearing fluids at the time of their formation and their release from the sources (Dickin, 2018 and references therein); (iii) its concentration and isotopic composition may provide information about fluid sources, elements partitioning, isotopic mixing behavior and extent of fluid-rock interaction (Banner, 1995). In situ approaches applied to carbonates can therefore provide the spatial resolution to better constrain the carbon-volatile-element mobilization in a crust-mantle interface and the element exchange at grain-scale.

\section{Geology and petrology of the Ulten Zone}

In the Ulten Valley and Non Valley (Trentino-Alto Adige, Italy), the Ulten Zone is a tectonometamorphic complex belonging to the Tonale Nappe, Upper Austroalpine domain of the Eastern Alps (Fig.1). The Tonale Nappe forms a SW-NE oriented narrow belt of Variscan metamorphic rocks, bounded by Alpine faults such as the Tonale and Giudicarie lines to the South and the Peio Line to the North (Müller et al., 2001). The UZ consists of strongly foliated garnet-kyanite gneisses and migmatites enclosing lenses of peridotites and pyroxenites (Obata and Morten, 1987). The main metamorphic overprint is Variscan in age whereas the evidences of a weak Eo-Alpine overprint mostly occur along the main tectonic lines (Godard et al., 1996).

Considering the different grain size and metamorphic assemblage, Obata and Morten (1987) classified the UZ peridotites as ranging from less deformed coarse-grained spinel peridotites to foliated fine-grained garnet-amphibole/chlorite-amphibole peridotites: the latter are interpreted as deformed and recrystallized derivatives of the former.

The UZ petrology and metasomatic evolution is the subject of several studies well summarized in Scambelluri et al. (2010) and the sketch of Figure 2 contains the main features of an otherwise 
complex sequence of events. In stage 1 (Fig. 2), coarse-grained peridotites made of olivine + enstatite + diopside + Cr-Al spinel with protogranular texture (Obata and Morten, 1987) were percolated by hydrous basic melts from deeper lithospheric mantle before the Variscan orogeny, leading to LREE and LILE enrichment at spinel facies conditions $\left(1200^{\circ} \mathrm{C}\right.$ and $1.3-1.6 \mathrm{GPa}$; Nimis and Morten, 2000).

During stage 2, related to the Variscan subduction, corner flow dragged the coarse-peridotites close to the slab-wedge interface and caused the transition to porphyroclastic to fine-grained equigranular peridotites. The porphyroclastic type shows garnet corona around spinel and the occurrence of pale green amphibole in the peridotite matrix (Obata and Morten, 1987). However, well preserved spinel-facies coarse-peridotites are fairly rare in the field and the transitional evolution of the different lithotypes is still somewhat enigmatic.

Fine-grained peridotites show different mineral assemblages, mainly distinguished by the presence/absence of garnet and clinopyroxene, ranging from olivine + orthopyroxene + clinopyroxene + garnet + Ca-amphibole \pm spinel to olivine + orthopyroxene + Ca-amphibole + chlorite (Obata and Morten, 1987). Phlogopite, apatite, dolomite and rare dissakisite-(La) are accessories (Tumiati et al., 2007). Fine-grained peridotites resulted from mylonitization and hydration of the coarse-peridotites that interacted with slab-derived fluids during the Variscan continental collision. The metamorphic peak was estimated around $850^{\circ} \mathrm{C}$ and $2.0-2.5 \mathrm{GPa}$ in eclogite-facies conditions (Nimis and Morten, 2000; Braga and Sapienza, 2007), concomitant to a widespread crystallization of LILE- and LREE-rich amphibole, in textural equilibrium with garnet (Scambelluri et al., 2006). The timing of tectonic emplacement into the crust is still uncertain: garnet-whole rock and garnet-clinopyroxene isochrones Sm-Nd ages of Tumiati et al. (2003) suggest that garnet-facies equilibration and metasomatism in peridotite, and country rocks migmatization occurred at the same time, about 340-330 Ma. This argument supported the notion that the tectonic insertion of peridotite into the subducted continental crust occurred at peak 
113 conditions (Tumiati et al., 2003). Conversely, Scambelluri et al. (2006) stressed that the 114 incorporation of mantle wedge peridotites into the crustal slab to form a crust-mantle mélange 115 likely occurred shortly after the metamorphic peak.

116 Stage 3 (Fig. 2) represents the retrograde evolution of the crust-mantle association, recorded by (i)

117 kelyphitic coronas around garnet in fine-grained garnet-amphibole peridotites (Godard and Martin, 118 2000) and (ii) the occurrence of fine-grained spinel/chlorite-amphibole peridotite, interpreted as 119 retrograde derivates from garnet-peridotites (Obata and Morten, 1987; Braga and Sapienza 2007;

120 Marocchi et al., 2007). All the UZ lithotypes experienced a post-Variscan exhumation and were 121 subjected to variable degrees of serpentinization that in some instances erased the previous texture 122 of peridotites.

123 The petrographic evidence of amphibole and minor dolomite requires carbon bearing hydrous 124 metasomatic agents. The origin of the hydrous metasomatic fluids with a $\mathrm{CO}_{2}$ component were at 125 first interpreted by Rampone and Morten (2001) as residual fluids left after the crystallization of 126 leucosomes of the host migmatite during the Variscan subduction. On the other hand, Scambelluri 127 et al. (2006) emphasized that fluids interacted with the peridotites while the latter still resided in the 128 mantle wedge (i.e. not within a crust-mantle mélange); moreover, the origin of metasomatic fluids 129 were related to the reaction of hydrous anatectic melts with wedge peridotite at the slab-wedge 130 boundary. This reaction produced an orthopyroxene-rich layer and LILE-rich residual fluids 131 forming the garnet + amphibole peridotites. Later studies (Marocchi et al., 2007; Ionov et al., 2017) 132 suggested that the migmatization of the host gneisses plausibly acted only during late stages of 133 metasomatism, while the main metasomatic episodes were governed by slab-derived crustal fluids 134 equilibrating with the lithospheric mantle prior to the Variscan subduction.

135 Dolomite, previously found in all UZ textural types, is the main C-repository (Sapienza et al., 2009; 136 Förster et al., 2017; Gudelius et al., 2018). Trace elements analyses of dolomite from stage 2 and 137 stage 3 peridotites indicate that dolomite represents the major repository also for $\mathrm{Sr}, \mathrm{Ba}, \mathrm{Pb}$ and 
138 subordinately LREE (Sapienza et al., 2009). Smaller amounts of magnesite are reported by

139 Malaspina and Tumiati (2012) in a fine-grained porphyroclastic garnet peridotite and by Förster et 140 al. (2017) in a coarse-grained protogranular peridotite. Only recently, evidences for carbonate 141 dissolution-reprecipitation processes in these peridotites have been reported (Förster et al., 2017).

\section{Analytical methods}

Scanning electron microscopy (SEM), Electron probe microanalysis (EPMA)

144 Silicates, carbonates, oxides and sulfides were investigated with SEM and EPMA. Petrographic 145 thick sections (ca. $100 \mu \mathrm{m}$ of thickness) and peridotite chips with $5 \mathrm{~mm}$ of thickness were gold 146 coated for SEM analyses. BSE images were acquired at the Dipartimento di Scienze Biologiche 147 Geologiche e Ambientali, Università di Bologna, using a Scanning Electron Microscope (SEM) 148 Philips 515B fitted with an EDAX DX4 microanalytical device. The operating conditions were: 149 accelerating voltage of $15 \mathrm{kV}$, beam current of $2 \mathrm{nA}$ and a spot size $\sim 1 \mu \mathrm{m}$. Major element 150 compositions were determined with the JEOL 8100 SUPERPROBE electron microprobe at the 151 Institute of Mineralogy and Petrography, University of Innsbruck, with the analytical conditions: 15 $152 \mathrm{kV}$ accelerating voltage, $10 \mathrm{nA}$ beam current, using wavelength-dispersive spectroscopy (WDS). F153 topaz $(\mathrm{F})$, jadeite $\left(\mathrm{Na}_{2} \mathrm{O}\right)$, orthoclase $\left(\mathrm{K}_{2} \mathrm{O}\right)$, rutile $\left(\mathrm{TiO}_{2}\right)$, rhodonite $(\mathrm{MnO}), \mathrm{MgO}$, diopside $(\mathrm{CaO})$, 154 chromite $\left(\mathrm{Cr}_{2} \mathrm{O}_{3}\right)$, almandine $(\mathrm{FeO})$, corundum $\left(\mathrm{Al}_{2} \mathrm{O}_{3}\right)$, atacamite $(\mathrm{Cl})$, baryte $(\mathrm{BaO})$, Ni-olivine $155(\mathrm{NiO})$, and quartz $\left(\mathrm{SiO}_{2}\right)$ were used as standards for silicates and oxides analyses, while calcite $156(\mathrm{CaO})$, diopside $(\mathrm{MgO})$, strontianite $(\mathrm{SrO})$, rhodonite $(\mathrm{MnO})$ and almandine $(\mathrm{FeO})$ standards were 157 used for carbonates analyses. To avoid carbonate devolatilization during EPMA, the electron beam 158 was defocused to an approximate size of 10x10 microns. 
160 Micro-Raman spectroscopy was performed for the identification of the serpentine phases and

161 calcite + brucite intergrowths at the Department of Mathematical, Physical and Computer Sciences, 162 University of Parma. Polished thick sections and rock chips were investigated with a Horiba Jobin163 Yvon LabRam apparatus, equipped with an Olympus microscope with 10x, 100x and ultra long 164 working distance (ULWD) 50x objectives and motorized x-y stage. The $473.1 \mathrm{~nm}$ line of a doubled $165 \mathrm{Nd}$ :YAG diode pumped laser was used as excitation source with a spectral resolution of about $2 \mathrm{~cm}^{-}$

166 . The $473.1 \mathrm{~nm}$ source was selected to work in the spectra range with the maximum sensitivity of 167 the detector to enhance the $\mathrm{OH}$ stretching signal of the water molecules in the high wavenumber 168 range (3000-4000 $\left.\mathrm{cm}^{-1}\right)$. The spectra were collected using the ULWD 50X objective with repeated 169 acquisition. The background subtraction of each spectrum was performed with the LabSpec $^{\circledR}$ 170 software.

In situ Laser Ablation MC-ICP-MS analyses

173 In situ $\mathrm{Sr}$ isotopes of carbonates occurring in three thick sections and four rock chips of $5 \mathrm{~mm}$ 174 thickness, representing both fine- and coarse- grained peridotites, were measured at the Centro 175 Interdipartimentale Grandi Strumenti (CIGS) of the University of Modena and Reggio Emilia 176 (Italy) using a double focusing MC-ICP-MS with a forward Nier-Johnson geometry (Thermo 177 Fisher Scientific, Neptune ${ }^{\mathrm{TM}}$ ), coupled to a $213 \mathrm{~nm} \mathrm{Nd:YAG} \mathrm{laser} \mathrm{ablation} \mathrm{system} \mathrm{(New} \mathrm{Wave}$ 178 Research $^{\mathrm{TM}}$ ). The analytical procedure is the same as of Giovanardi et al. (2018).

179 Laser ablation parameters consisted of a laser spot ranging from $55 \mu \mathrm{m}$ to $100 \mu \mathrm{m}$ (see Table 4), a 180 fluence of $\sim 10 \mathrm{~J} / \mathrm{cm}^{2}$, a laser frequency of $\sim 10 \mathrm{~Hz}$ and a He flux of $\sim 0.5 \mathrm{~L} / \mathrm{min}$. Signals were 181 acquired in static mode with a block of 250 cycles (including laser warm-up, 50-80 cycles of 182 analysis and washout) and an integration time of $0.5 \mathrm{~s}$. Collected $\mathrm{m} / z$ were $82 \mathrm{Kr}, 83 \mathrm{Kr}, 84 \mathrm{Sr}, 85 \mathrm{Rb}$, $183 \quad 85.5,86 \mathrm{Sr}, 86.5,87 \mathrm{Sr}$ and $88 \mathrm{Sr}$. Masses 85.5 and 86.5 were measured to check doubly charged $\mathrm{Yb}$ 184 interferences. $\mathrm{Kr}$ was corrected measuring $60 \mathrm{~s}$ of gas blank with the laser off. After background 
185

subtraction, the remaining signal on mass 82 was used to check the formation of $\mathrm{Ca}$ dimers and argides; while mass 83 to check the presence of $\mathrm{Er}^{2+}$. $\mathrm{Rb}$ was corrected by calculating the ${ }^{87} \mathrm{Rb}$ contribution to mass 87 by measuring the interference-free ${ }^{85} \mathrm{Rb}$ signal, correcting for instrumental mass fractionation, and using the natural ${ }^{87} \mathrm{Rb} /{ }^{85} \mathrm{Rb}$ ratio. Mass bias normalization was performed through exponential law and a ${ }^{88} \mathrm{Sr} /{ }^{86} \mathrm{Sr}$ ratio of 8.375209 . The accuracy of the analyses was checked using an in-house reference material (modern marine shell) (see Table X in Supplementary Material), which yielded a ${ }^{87} \mathrm{Sr} /{ }^{86} \mathrm{Sr}$ ratio of $0.709174 \pm 0.000064(2 \sigma ; \mathrm{n}=19)$, in agreement with modern seawater $(0.70917)$. Three analyses of a second in-house carbonate reference material yielded $\mathrm{a}^{87} \mathrm{Sr} /{ }^{86} \mathrm{Sr}$ ratio of $0.707562 \pm 0.000018(2 \sigma)$, equal to the solution reference value $(0.70756$ $\pm 0.00003 ; 2 \sigma$ ) (Weber et al., 2019). Data reduction was performed using a customized excel spreadsheet.

\section{Results}

\subsection{Sample description and petrography}

Peridotite samples were collected from the Northeastern part of the UZ (Fig.s 1 and 3), from outcrops or boulders very close to the outcrops (Table 1 for sample description, location) (Fig.3). Each sample underwent weak up to very strong serpentinization that in some instances overprinted the previous textures. All the samples investigated contain carbonates such as dolomite and, locally, magnesite and calcite (see Table 1). From now on, the numbers 1 and 2 refer to first and second generation respectively of olivine, orthopyroxene, clinopyroxene and spinel.

Samples 18LP1 and MOL1-C are coarse-type spinel peridotites consisting mainly of large (1-4 mm) olivine $_{1}$, orthopyroxene ${ }_{1}$ and spinel $_{1}$. Sample 18LP1 shows orthopyroxene ${ }_{1}$ with undulose extinction and kink bands and they are usually surrounded by a chlorite rim with a diameter of about $150 \mu \mathrm{m}$. Clinopyroxene ${ }_{1}$, exhibiting amphibole and spinel exsolutions, is associated with nearly-dark vermicular spinels ${ }_{1}$. The studied chip rock contains a $300 \mu \mathrm{m}$ wide veinlet crosscutting 
210 the matrix and filled with dolomite associated with colorless amphibole and chlorite; here, dolomite 211 occurs as lobate-shaped grains (Fig. 5a). This veinlet is perpendicularly crosscut in several places 212 by thin (ca. $50 \mu \mathrm{m}$ wide) serpentine veins that locally contain dolomite streaks (ca. $25 \mu \mathrm{m}$ wide) 213 (Fig. 5b). Sample MOL1-C does not contain clinopyroxene ${ }_{1}$ and mainly consists of strongly 214 fractured olivines ${ }_{1}$ and orthopyroxenes ${ }_{1}$ showing kink bands. Vermicular dark spinel is often 215 included in coarse green amphiboles. The sample shows a ca. $300 \mu \mathrm{m}$ wide veinlet consisting of 216 magnesite, serpentine, colorless amphibole and opaque minerals (Fig. 5c) cuts by a dolomite vein 217 (ca. $200 \mu \mathrm{m}$ long) (Fig. 5d). When the magnesite + serpentine + colorless amphibole vein 218 encounters coarse crystals of orthopyroxene $e_{1}$, serpentine minerals grow along orthopyroxene $e_{1}$ 219 cleavages promoting a black-colored needle-like serpentine microstructure (Fig.s 4a and 5c). Both 220 coarse peridotites probably escaped full mineralogical equilibration under eclogite-facies 221 conditions, as indicated by the absence of garnet.

222 Fine-grained peridotites are the most common textural rock type in the UZ. They show grain sizes 223 smaller than $0.7 \mathrm{~mm}$ and exhibit porphyroblastic to equigranular textures. Sample VM10A is a fine224 grained mylonitic garnet-amphibole-peridotite with a main foliation defined by the preferred 225 orientation of matrix minerals. The main mineralogical association consists of fine-grained olivine ${ }_{2}$, 226 orthopyroxene $_{2}$, green amphibole, spinel $_{2}$ with accessory matrix dolomite (ca. $\left.60 \mu \mathrm{m}\right)($ Fig. 5e) 227 associated with apatite and green amphibole. Allanite locally occurs in the matrix. A porphyroclast 228 (ca. 1cm) of highly fractured reddish zircon occurs in this rock; it contains a mm-sized dolomite 229 inclusion associated with apatite. Rare small-sized pinkish-garnets occur.

230 Samples KL2.4-2b and KL2.4-3 are fine-grained garnet-amphibole peridotites and contain 231 porphyroblasts of coarse pink garnet (ca. $1 \mathrm{~cm}$ of size) surrounded by a kelyphitic corona made of 232 orthopyroxene + amphibole + clinopyroxene \pm spinel (Fig. 4b). These garnets are highly fractured 233 and contain mm-sized spinel $_{1}$ inclusions. This spinel ${ }_{1}$ locally hosts polycrystalline aggregates 
consisting of (i) apatite, ilmenite, pentlandite, calcite-brucite intergrowths and phlogopite; (ii)

235 ilmenite, chlorite, apatite, pentlandite. The KL2.4-2b sample description is reported in detail by 236 Förster et al. (2017), who also documented the occurrence of a dolomite inclusion (ca. $70 \mu \mathrm{m})$ in a 237 primary spinel included in coarse-grained garnet. Matrix dolomite (ca. $40 \mu \mathrm{m}$ ) occurs commonly in 238 association with green amphibole and apatite. In both samples, calcite occurs as thin veins in the 239 matrix (Fig. 5g), included in chlorite and, in some instances, forming intergrowths with brucite. 240 Two generations of serpentine minerals occur, with the first one represented by mesh structure in 241 olivine $_{2}$ and bastite in orthopyroxene ${ }_{2}$ and the second one forming thin veins crosscutting the matrix 242 with the porphyroblastic garnet and keliphitic corona.

243 Sample KL1-A is a fine-grained garnet-amphibole peridotite with the same mineralogy of the 244 previous samples but equigranular texture (ca. $300 \mu \mathrm{m})($ Fig. 4c). Here, intergrowths of calcite + 245 brucite associated with relict dolomite occur in the matrix (Fig. 5f). Widespread small-sized 246 pinkish-garnets $(200-300 \mu \mathrm{m})$ occur interstitially in the matrix, always exhibiting a kelyphitic 247 corona of orthopyroxene + amphibole + clinopyroxene \pm spinel. This peridotite sample shows 248 mesh and bastite replacement textures of olivine and pyroxene respectively. This sample is also 249 pervaded by thin veins of serpentine and chlorite crosscutting the matrix (Fig. 4c).

250 Sample MM1 is a fine-grained amphibole-chlorite peridotite. This sample comes from a well251 studied outcrop which provided sample 300B studied by Morten and Obata (1990), Scambelluri et 252 al. (2006) and Braga and Sapienza (2007). Particularity of the sample is the presence of a ca. $1 \mathrm{~cm}$ 253 wide serpentine vein showing concentric zonation with a core filled by magnetite and pentlandite 254 and minor dolomite and calcite, and a border zone including matrix minerals consisting of olivine ${ }_{2}$, 255 orthopyroxene $_{2}$, green amphibole and spinel 2 (see Figs. 5a-b-c-d and S1a-b-c-d in Supplementary 256 Material). Matrix dolomite is estimated to occur with an abundance of $2 \%$, with a grain-size range 257 of about $50-100 \mu \mathrm{m}$ and commonly associated with apatite (Figs. 5h and S1b in Supplementary 258 Material). 


\subsection{Major element compositions and micro-Raman spectroscopy}

260 Representative major element compositions of silicate minerals and apatites are listed in Table 2 261 (for all the EPM analyses see Supplementary Material ST-I and ST-IX) while all the carbonates 262 major element compositions are listed in Table 3. The major element compositions commonly do 263 not exhibit variations between coarse-grained and fine-grained rocks and minerals of different 264 generations. Olivine is unzoned with $\mathrm{Fo}_{88-90} \mathrm{Teph}_{0-2}$. Orthopyroxene is commonly $\mathrm{En}_{90-92} \mathrm{Fs}_{8-10} \mathrm{Wo}_{0-1}$ 265 with $\mathrm{Al}_{2} \mathrm{O}_{3}$ reaching values up to $2.80 \mathrm{wt} . \%$. Two textural-types of spinel are recognized: a first 266 generation of coarse spinel $_{1}$ included in porphyroblastic garnets exhibits $\mathrm{Cr} \# \sim 0.43$, where $\mathrm{Cr} \#$ is $267 \mathrm{Cr} /(\mathrm{Cr}+\mathrm{Al})$, while the second generation of matrix smaller $\operatorname{spinel}_{2}$ has $\mathrm{Cr} \#$ of about 0.35 . 268 Clinopyroxene is always diopside $\left(\mathrm{En}_{46-49} \mathrm{Fs}_{2-3} \mathrm{Wo}_{47-50}\right)$. Green amphibole in the matrix is commonly 269 Mg-hornblende and minor pargasite (in samples KL2.4-2b and KL2.4-3). Pargasite is often rimmed 270 by colorless tremolitic amphibole $\left(\mathrm{Al}_{2} \mathrm{O}_{3} \sim 0.25\right.$ wt.\%). Considering the three amphibole-types, $271 \mathrm{Na}_{2} \mathrm{O}$ and $\mathrm{Al}_{2} \mathrm{O}_{3}$ contents range from 0.1 to 1.6 wt.\% and from 0.25 to $16.6 \mathrm{wt} \%$, respectively. 272 When amphibole occurs in veinlets, its composition is always tremolitic (i.e. magnesite vein with 273 tremolite and serpentine). Unzoned garnet is pyrope-rich $\left(\mathrm{Py}_{51-70} \mathrm{Alm}_{17-30} \mathrm{Sps}_{1-4} \mathrm{Grs}_{11-15}\right)$ showing 274 little to no compositional variations between porphyroclasts and small-sized garnets. Apatite, 275 always in association with dolomite, exhibits a high $\mathrm{Cl}$ content of about 5 wt.\%. Serpentine 276 (lizardite) replacing olivine and pyroxenes exhibits a Fe content ranging from 1.53 to 9.02 wt.\% 277 FeO. In the fine-grained amphibole-chlorite peridotite sample MM1, a composite serpentine vein 278 was characterized by micro-Raman spectroscopy showing lizardite and mixed lizardite/chrysotile 279 compositions (Fig. S1 in Supplementary Material). Sheet silicates, represented by chlorite and 280 phlogopite, show Fe contents of 2.22-2.55 and 3.45-5.03 wt.\% FeO respectively. The $\mathrm{Na}_{2} \mathrm{O}$ content 281 of phlogopite reaches values of $0.13 \mathrm{wt} . \%$. 
282 Carbonate compositions are given in the $\mathrm{MgCO}_{3}-\mathrm{CaCO}_{3}-\mathrm{FeCO}_{3}$ ternary diagram (Fig. 6). Unzoned 283 dolomite does not exhibit any compositional variations between the different peridotites and 284 microstructural domains. It can be classified as ferroan-dolomite, with $X_{\mathrm{FeCO}}$ of about 0.02 in all 285 the samples. Similarly, magnesite veinlet shows high Fe content, with $X_{\mathrm{FeCO} 3}$ of about 0.05 . Calcite 286 (together with brucite) was identified using micro-Raman spectroscopy (see Fig S2 in 287 Supplementary Material for the Raman spectrum), and it also occurs as thin veins cutting the matrix 288 or as intergrowths with brucite in association with dolomite (Fig. 7). Calcite composition is close to 289 the Ca-carbonate endmember (Fig. 6).

\subsection{Sr isotope composition of Ulten Zone carbonates}

291 In situ ${ }^{87} \mathrm{Sr} /{ }^{86} \mathrm{Sr}$ isotope ratio analyses are listed in Table 4. Carbonates were previously chosen and 292 detected considering the grain size, the Sr concentration and the microstructural domain. Dolomite 293 is the main C-repository, showing a grain size of mostly 30-70 $\mu \mathrm{m}$. Calcite veins are too narrow (ca. $29420-30 \mu \mathrm{m}$ wide) to be measured by LA-MC-ICP-MS, while magnesite does not contain $\mathrm{Sr}$ (see 295 Table IX in Supplementary Material). For this study we performed thirty-nine in situ analyses. Spot 296 size analyses ranges between 55 and $100 \mu \mathrm{m}$, in relation to the carbonate size (see Table 4). The $297{ }^{87} \mathrm{Sr} /{ }^{86} \mathrm{Sr}$ isotope ratios obtained for all the dolomites are reported in Figure 8 and range between $2980.70360 \pm 0.00007$ and $0.71184 \pm 0.00026(n=36)$. The distribution of Sr isotopic compositions of 299 all carbonates analyzed is shown in Figure 8.

300 In the coarse-type spinel peridotite $18 L P 1$, the dolomite vein associated with tremolite and chlorite 301 exhibits highly variable $\mathrm{Sr}$ isotopic values ranging from $0.70360 \pm 0.00007$ to $0.70830 \pm 0.00015$ 302 (n=12) (Figs. 8 and 9). Two lobate-shaped dolomite grains (spots 5, 8) shown in Figure 9 exhibit 303 the lowest values of all UZ carbonates analyzed. In MOL1-C late vein dolomite cutting a magnesite 304 vein (Fig. 5d) gives an average value of $0.71184 \pm 0.00026(n=2)$, representing the highest 305 radiogenic ratio obtained by the in-situ $\mathrm{Sr}$ measurements of all Ulten carbonates-bearing peridotites 306 of this study. 
307 In three fine-grained peridotites, both dolomite and (when possible) calcite were analyzed. In Figure

3088 it can be observed that the $\mathrm{Sr}$ isotopic ratio of matrix dolomite is nearly-homogeneous within the 309 same sample and, conversely, different values were obtained from the different fine-type 310 peridotites. In the mylonitic garnet-amphibole peridotite $V M 10 A$, the ${ }^{87} \mathrm{Sr} /{ }^{86} \mathrm{Sr}$ ratio of matrix 311 dolomite is $0.70529 \pm 0.00011(\mathrm{n}=4)$. In the same sample, a large dolomite inclusion (ca. $7 \mathrm{~mm}$ 312 long) occurring in a zircon porphyroclast exhibits a ${ }^{87} \mathrm{Sr} /{ }^{86} \mathrm{Sr}$ ratio of $0.70597 \pm 0.00007$, obtained 313 by analyzing a line scan along the carbonate grain. In the fine-grained garnet-amphibole peridotite $314 \mathrm{KLI}-\mathrm{A}$, the dolomite ${ }^{87} \mathrm{Sr} /{ }^{86} \mathrm{Sr}$ ratio is $0.70671 \pm 0.00021$ whereas calcite (associated to brucite) 315 gives slightly higher radiogenic values of about $0.70719 \pm 0.00018(n=3)$. It is worth noting that, 316 given the small size of calcite and brucite and their textural interconnection, both of them were 317 included in the spots analyses. However, brucite is not supposed to incorporate $\mathrm{Sr}^{2+}$ and we 318 therefore consider our data as exclusive for calcite. Average value of matrix dolomite in fine319 grained amphibole-chlorite peridotite $M M 1$ is $0.70487 \pm 0.00010(\mathrm{n}=16)$.

\section{Discussion}

321 Petrographic data indicate that the UZ peridotites, during their complex metasomatic history, underwent carbonation and, locally, dolomite dissolution and calcite reprecipitation. To date, the crustal portion of the subducted continental slab has been considered as the source of the several metasomatic fluids that interacted with the UZ peridotites (Rampone and Morten, 2001;

325 Scambelluri et al., 2006; Sapienza et al., 2009). The presence of hydrous phases (dissakisite-Ce, amphibole and minor phlogopite) enriched in LILE, Th, U, and LREE compared to other incompatible trace elements, as well as the occurrence of large zircon grains (Forster et al., 2017; this study), strongly support this interpretation. On the basis of textures, bulk rock and mineral major and trace element compositions, Ionov et al. (2017) suggested that most of the "crustal" overprint of the UZ occurred into the mantle wedge well below the crust (ca. $850^{\circ} \mathrm{C}$ at $60-90 \mathrm{~km}$ 
331 depths), in a supra-subduction setting similar to the mantle wedge sampled by harzburgite xenoliths

332 from the western Pacific. Given the uncertainty of 'crustal' vs 'mantle' origin of metasomatizing

333 fluids, the Sr concentration and isotopic signature of carbonates of the UZ peridotites may help to

334 shed light on these contrasting views.

335 We will focus on C-related processes by simply dividing the metasomatic evolution into two main

336 stages: (1) the HP carbonation of mantle wedge peridotites at peak (eclogite-facies) conditions and 337 during their early exhumation up to mid-crust depth and (2) the carbon re-mobilization via fluid338 rock interaction during the final exhumation of the crust-mantle mélange, which formed after the 339 incorporation of mantle slivers into the subducted continental crust. The tectonic insertion of the 340 peridotites into the host gneiss is believed to have occurred after peak pressure conditions 341 (Scambelluri et al. 2006). We discuss these two processes separately, referring to them as Stage1 342 and Stage 2.

\section{$343 \quad 5.1$ Stage 1: HP carbonation.}

\section{$344 \quad$ Included and interstitial dolomite}

345 The onset of the metasomatic history of the UZ peridotites started with percolation of melts into the 346 spinel-facies mantle wedge, causing the formation of pyroxenite layers (Nimis and Morten, 2000). 347 At this stage there is no petrographic evidence of carbonation. Conversely, the occurrence of lobate348 shaped dolomite inclusion in a porphyroclastic zircon and matrix dolomites in the fine-grained, 349 garnet-bearing peridotites suggests that carbonation occurred when the Ulten peridotites reached 350 peak eclogite-facies conditions (Fig.10). If zircon and dolomite formation are coeval as the 351 petrographic observation suggests, a time constraint for this early episode of carbonation can be 352 provided by the $333 \mathrm{Ma} \mathrm{U}-\mathrm{Pb}$ age of zircon from metasomatic reaction bands at the Mt. Hochwart 353 gneiss-peridotite contact (Tumiati et al., 2007), the same locality of sample VM10A of this study. 
354 Furthermore, in another fine-grained garnet-bearing peridotite we have a unique microstructural 355 evidence of a dolomite inclusion in Cr-spinel, which is included in a porphyroclastic garnet. Major elements composition obtained with EPMA shows that this inclusion has the same composition as the matrix dolomite and dolomite veins. The origin of this inclusion is yet unknown (i.e. mantle provenance or subducted continental crustal derivation), but the occurrence of fractures in the host garnet may suggest that dolomite precipitation could have been induced during C-rich fluids percolation after spinel and garnet crystallization (in contrast to the interpretation of an early meltrelated process in the high- $T$ spinel stage given by Förster et al., 2017). At peak conditions, fluids prompted the precipitation of interstitial dolomite.

During continental collision, the crustal portion of the descending slab consists of the sedimentary cover and its underlying crystalline basement. The subducted lithologies may release fluids into the overhanging mantle wedge and their source can be investigated, at least in part, by considering fluid mobile elements (FME) such as $\mathrm{Sr}$ and the ${ }^{87} \mathrm{Sr} /{ }^{86} \mathrm{Sr}$ isotopic ratio. Different sources of the metasomatic liquids were considered for the $H P$-dolomite (both included and interstitial), as reported in Figure 11: (i) associated stromatic gneisses and orthogneisses; (ii) Devonian sedimentary cover; (iii) lithospheric mantle; (iv) trondhjemitic dykes and pockets.

(i) Based on literature, we expected similar $\mathrm{Sr}$ isotopic ratio for the carbonates and the

(ii) It is difficult to assess the role of a sedimentary cover overlying the crystalline basement because of the lack of field evidence of Paleozoic sedimentary successions associated with the UZ crust-peridotite association. Subducted marine carbonates along the oceanic crust subduction prior to the subduction of the continental crust may also play a role in 
the formation of carbonates in the mantle wedge. However, $\mathrm{Sr}$ isotope values reported by van Geldern et al. (2006) for well-preserved Devonian brachiopod shells ( $\mathrm{Mn}<100$ ppm; $\mathrm{Fe}<400 \mathrm{ppm}$ and $\mathrm{Sr}>500 \mathrm{ppm}$ ) range from 0.70782 to 0.70804 (during the Emsian-Eifelian boundary and early Famennian respectively), unlikely representing the required sources for the interstitial dolomite in the matrix.

(iii) The relatively unradiogenic values of matrix carbonates have $\mathrm{Sr}$ isotopic values close to those of the coarse-grained spinel-garnet peridotites of Tumiati et al. (2003), as shown in

(iv) The radiogenic Sr signature of few trondhjemitic dykes and pockets described by Del Moro et al. (1999) are close to those reported for the matrix dolomite of the fine-grained mylonitic garnet-amphibole peridotite VM10A from Mt. Hochwart. Based on petrology and whole-rock Sr-Nd isotope geochemistry, Del Moro et al. (1999) interpreted the UZ trondhjemite as melts produced by fluid-assisted anatexis of a metasedimentary lower crust characterized by low $\mathrm{Rb} / \mathrm{Sr}$ and $\mathrm{Sr}$ isotope ratios. Once formed, the trondhjemite melts intruded the UZ migmatitic crust.

\section{Localized carbonation: carbonates veinlets.}


403 The tectonic insertion of mantle material into the crustal portion of the continental slab occurred 404 after the attainment of maximum pressure conditions, i.e. at the beginning of the exhumation 405 (Scambelluri et al., 2006). During this early phase of upwelling of the crust-mantle mélange, 406 dolomite veins associated with tremolite and chlorite and magnesite + lizardite-crysothile + 407 tremolite vein within the two coarse-type spinel peridotites are indicative that carbonation occurs as 408 local injection of C-rich fluids (Fig. 10) under different retrograde $P$ - $T$ conditions. The mineral 409 assemblage of the dolomite + tremolite + chlorite vein supports the evidence of a retrograde process 410 prior to serpentinization $\left(650^{\circ} \mathrm{C} \leq \mathrm{T} \leq 700^{\circ} \mathrm{C}\right.$ at $P$ of ca. $\left.1 \mathrm{GPa}\right)$ and, in addition, provides a 411 minimum $P-T$ estimate for the formation of the crust-mantle mélange.

412 The Sr isotopic heterogeneity (0.7035-0.7085; Figs. 8 and 9) measured in different dolomite grains 413 from the dolomite + tremolite + chlorite vein encompasses the ${ }^{87} \mathrm{Sr} /{ }^{86} \mathrm{Sr}$ values measured from 414 matrix and included dolomite. Most of the inter-grain variability can be explained by the interaction 415 of the matrix and the included dolomite, which show low-Sr isotopic values, with progressively 416 more radiogenic fluid, as it would be expected in mantle rocks closely associated with crustal 417 lithologies. Similarly, late-stage carbonate veins in kimberlites from Beinfontein show a large 418 variability of the Sr-isotope composition, reaching values of $0.70957 \pm 116(2 \sigma)$. These results were 419 interpreted as a consequence of primary carbonates interaction with crustal fluids (Castillo-Oliver et 420 al., 2018), as we speculate for the UZ dolomite veins. It is not easy to explain the occurrence of low $421{ }^{87} \mathrm{Sr} /{ }^{86} \mathrm{Sr}$ ratios $(0.7036-0.7039$; Figs. 8 and 9) of two dolomite grains in this vein. As shown in Fig. 422 11, these values approach the MORB signature, thus requiring a distinct metasomatic agent with a 423 Sr signature typical of a mantle reservoir depleted in radiogenic Sr. This metasomatic agent 424 depleted in radiogenic Sr precipitated primary carbonates that did not interact with late-stage 425 metasomatic crustal fluids.

426 The occurrence of a magnesite vein associated with lizardite-chrysotile and tremolite suggests 427 influx of a local carbonaceous fluid at $\mathrm{T}<600^{\circ} \mathrm{C}$ during the retrograde path. This vein is cut by a 
428 dolomite vein with the highest ${ }^{87} \mathrm{Sr} /{ }^{86} \mathrm{Sr}$ ratio (0.7118-0.7119; Figs. 5d and 8), which formed after 429 the previously discussed vein dolomite. The highly radiogenic values of this vein suggest that this 430 episode of injection of C-rich fluids occurred when the orogenic mélange, characterized by mingled 431 crustal and mantle components, was already well developed and that infiltrating C-rich crustal 432 fluids introduced significant amounts of radiogenic Sr (Fig. 11). According to the geodynamic 433 scenario of Ranalli et al. (2005), this mélange was brought to mid-crustal depths between 330 and $434300 \mathrm{Ma}$ reaching $0.7 \mathrm{GPa}$ at $500^{\circ} \mathrm{C}$.

\subsection{Stage 2. Carbon re-mobilization via fluid-rock interaction}

436 Following the geodynamic model proposed by Ranalli et al. (2005), after the late Carboniferous fast 437 exhumation, the crust-mantle mélange underwent slow exhumation and cooling during Permian438 Triassic times (300-205 Ma). During this slow exhumation, Stage 2 carbonation is related to the 439 action of serpentinizing fluids, which in some instances erased the previous mantle texture. Here, C 440 re-mobilization via fluid-rock interaction prevails (blue arrow, Fig. 10) as evidenced by the 441 occurrence of (i) calcite + brucite intergrowths surrounded by serpentine (Figs. 5f and 7) and (ii) 442 thin calcite veins.

443 The calcite + brucite intergrowths are the result of dolomite breakdown during interaction with 444 aqueous fluids (Figs. 5f and 7) (Förster et al., 2017) and were found only in highly serpentinized 445 fine-grained garnet-bearing peridotites. Moreover, micro-Raman investigations allowed the 446 identification of lizardite as the serpentine phase surrounding these intergrowths. If serpentinizing 447 fluids were the cause of dolomite dissolution, we therefore argue that the precipitation of calcite + 448 brucite probably occurred at $P$ of about $0.5 \mathrm{GPa}$ and $T<300^{\circ} \mathrm{C}$. At this stage the Ulten basement 449 was likely subjected to isostatic adjustment after the conclusion of the Variscan collision (Ranalli et 450 al., 2005). 
451 The formation of thin calcite veins occurring in the matrix and in some instances crosscutting 452 spinel, chlorite and phlogopite, was interpreted by Förster et al. (2017) as a consequence of the 453 influx of serpentinizing fluids that triggered dissolution of the former dolomite and crystallization 454 of calcite + brucite intergrowths with concomitant liberation of $\mathrm{CO}_{2}$, following the reaction $455 \mathrm{CaMg}\left(\mathrm{CO}_{3}\right)_{2}+\mathrm{H}_{2} \mathrm{O} \rightarrow \mathrm{CaCO}_{3}+\mathrm{Mg}(\mathrm{OH})_{3}+\mathrm{CO}_{2}$. The release of $\mathrm{CO}_{2}$ may prompt in-situ 456 formation of carbonates (i.e. thin calcite veins) after $\mathrm{C}$ saturation was achieved.

457 During fluid-rock interaction, Sr preferentially partitions into the fluid phase (Banner et al., 1995) 458 and the aqueous serpentinizing fluids, characterized by ${ }^{87} \mathrm{Sr} /{ }^{86} \mathrm{Sr} \approx 0.7070-0.7075$, dissolved 459 dolomite that provided the local source of Sr. Eventually, the fluid enriched in $\mathrm{C}$ and $\mathrm{Sr}$ (from 460 dolomite) precipitated relatively Sr-rich calcite. The higher elemental $\mathrm{Sr}$ abundance with respect to 461 dolomite is due to the less incompatible behavior of $\mathrm{Sr}$ in calcite (Banner et al., 1995).

\section{Conclusion and future directions}

463 The combination of textural observation of carbonates with in situ $\mathrm{Sr}$ isotope analyses reveals a 464 more complex metasomatic evolution for the UZ peridotite than previously thought. In particular, 465 two main conclusions can be drawn: (1) at peak (eclogite facies) conditions, there is not a simple 466 carbon transfer between the crustal portion of a subducted continental and the overhanging wedge, 467 but additional $\mathrm{C}$ sources have to be considered and (2) at low-pressure conditions, during the final 468 exhumation stages of an already well developed crust-mantle mélange, the main carbonation 469 process implies dolomite breakdown and calcite reprecipitation by $\mathrm{H}_{2} \mathrm{O}$-rich fluids.

470 The relatively unradiogenic $\mathrm{Sr}$ isotope ratio recorded by includsion- and matrix dolomite, with 471 some grains of a dolomite vein, does not support a simple derivation from fluids derived from the 472 migmatite host gneisses (Fig. 11). The first stage of carbonation thus requires $H P$ metasomatic 473 fluids (i.e. at $\sim 2.5 \mathrm{GPa}$ and $850^{\circ} \mathrm{C}$ ) likely unrelated to the associated crust (stromatic gneisses and 474 orthogneisses), as already recognized by Marocchi et al. (2009; 2007). We suggest that these HP 
fluids may have variably equilibrated with a depleted lithospheric mantle before the crystallization

476 of matrix dolomite. Residual $\mathrm{COH}$ fluids originated from the crystallization of trondhjemite liquids 477 intrusion derived from deeper portions of the Ulten crust or fluids released from Paleozoic 478 carbonate succession and involved into the Variscan orogenesis can be considered as alternative 479 sources for the metasomatic agents infiltrating at peak conditions and before the onset of 480 serpentinization.

481 During the first stages of exhumation, C-bearing fluids were channeled into veins, giving rise to the 482 veinlet filled with dolomite associated with tremolite and chlorite, followed at lower $P$ - $T$ conditions 483 by the formation of the magnesite + lizardite-crysothile + tremolite veins. The fluids released by the 484 crystallization of leucosomes of the host migmatites, showing variable $\mathrm{CO}_{2} / \mathrm{H}_{2} \mathrm{O}$ ratios as inferred 485 by Rampone and Morten (2001), seem to be important metasomatic agents only at the end of the 486 exhumation of the crust-mantle mélange, at temperatures consistent with lizardite stability, 487 providing the highest $\mathrm{Sr}$ isotope values for the dolomite veins. The infiltration of serpentinizing 488 fluids represents the last metasomatic episode of peridotites, leading to C-remobilization by 489 dolomite dissolution and calcite precipitation with concomitant liberation of $\mathrm{CO}_{2}$.

490 Evidences of both HP carbonation and carbonates dissolution-reprecipitation make these rocks an 491 effective carbon locker and a "pit-stop" for C-remobilization through a mantle wedge. 492 Consequently, the results of this study have implications for the global comprehension of the so 493 called "Deep Carbon Cycle". While in situ Sr isotope data have demonstrated useful to give us 494 additional constrains on an overall complex multiphase metasomatic evolution, their main 495 limitation is the restriction to relatively large grains $(\geq 50 \mu \mathrm{m})$ and the less precision compared to 496 dilution techniques. However, our approach ensures the textural control that is mandatory when 497 multiple generations of metasomatic minerals occur in the same sample. The errors obtained for the 498 Ulten carbonates, moreover, are far lower than the variability observed, allowing to clearly 
distinguish the different isotope patterns. Future higher resolution in-situ $\mathrm{C}$ and $\mathrm{O}$ isotope analyses of carbonates will allow to better constrain the sources of these C-bearing metasomatizing fluids.

\section{Acknowledgements}

G. Gasparotto (University of Bologna), M. Tribus (University of Innsbruck) and Antonio Langone are thanked for assistance during SEM, EPMA and LA-ICP-MS analyses. Constructive reviews by Guilleume Delpech and Andrea Giuliani greatly improved this work. This research was supported by RFO and ALMAIDEA grants (University of Bologna).

\section{References}

Banner, J.L., 1995. Application of the trace element and isotope geochemistry of strontium to studies of carbonate diagenesis. Sedimentology 42, 805-824.

Bebout, G.E., Penniston-Dorland, S.C., 2016. Fluid and mass transfer at subduction interfaces. The field metamorphic record. Lithos 240, 228-258.

Braga, R., Sapienza, G.T., 2007. The retrograde evolution of a dolomite-bearing hydrous peridotite from the Ulten Zone (Italian Alps). GeoActa 6, 37-45.

Braga, R., Massonne, H.-J., 2012. $\mathrm{H}_{2} \mathrm{O}$ content of deep-seated orogenic continental crust: the Ulten Zone, Italian Alps, International Geology Review 54, 633-641.

Brueckner, H.K., Medaris, L.G., 2000. A general model for the intrusion and evolution of 'mantle'garnet peridotites in high-pressure and ultra-high-pressure metamorphic terranes. Journal of Metamorphic Geology 18, 123-133.

Castillo-Oliver, M., Giuliani, A., Griffin, W., L., O’Reilly, S., Y., 2018. Characterisation of primary and secondary carbonates in hypabyssal kimberlites: an integrated compositional and Srisotopic approach. Mineralogy and Petrology, 112, S555-S567.

Del Moro, A., Martin, S., Prosser, G., 1999. Migmatites of the Ulten Zone (NE Italy), a record of melt transfer in deep crust. Journal of Petrology 40, 1803-1826.

Dickin, A.P., 2018. Radiogenic isotope geology. $3^{\text {rd }}$ edition, Cambridge University Press, 482.

Evans, B.W., Johannes, W., Oterdoom, H., Trommsdorff, V. 1976. Stability of chrysotile and antigorite in the serpentinite multisystem. Schweizerische Mineralogische und Petrographische Mitteilungen, 56, 79-93.

Förster, B., Braga, R., Aulbach, S., Pò, D.L., Bargossi, G.M.G.M., Mair, V., 2017. A petrographic study of carbonate phases in the Ulten Zone ultramafic rocks: insights into carbonation in the mantle wedge and exhumation-related decarbonation. Ofioliti 42, 105-127.

Fumagalli, P., Poli, S., 2005. Experimentally determined phase relations in hydrous peridotites to $6.5 \mathrm{GPa}$ and their consequences on the dynamics of subduction zones. Journal of Petrology, $46,555-578$.

Gasparrini, M., Bechstädt, T., Boni, M., 2006. Massive hydrothermal dolomites in the southwestern Cantabrian Zone (Spain) and their relation to the Late Variscan evolution. Marine and Petroleum Geology 23, 543-568. 
Giovanardi, T., Mazzucchelli, M., Lugli, F., Girardi, V.A., Correia, C.T., Tassinari, C.C., Cipriani, A., 2018. Isotopic constraints on contamination processes in the Tonian Goiás Stratiform Complex. Lithos 310, 136-152.

Godard, G., Martin, S., Prosser, G., Kienast, J.R., Morten, L., 1996. Variscan migmatites, eclogites and garnet-peridotites of the Ulten zone, Eastern Austroalpine system. Tectonophysics 259, $313-341$.

Gudelius, D., Aulbach S., Braga, R., Höfer, H., Woodland, A.B., Gerdes A., 2018. Element transfer and redox conditions in continental subduction zones: new insights from peridotites of the Ulten Zone, North Italy. Journal of Petrology 60, 231-268.

Hermann, J., Zheng, Y.-F., Rubatto, D., 2013. Deep fluids in subducted continental crust. Elements 9, 281-287.

Ionov, D.A., Bigot, F., Braga, R., 2017. The Provenance of the Lithospheric Mantle in Continental Collision Zones: Petrology and Geochemistry of Peridotites in the Ulten-Nonsberg Zone (Eastern Alps). Journal of Petrology 58, 1451-1472.

Johannes, W., Puhan, D., 1971. The calcite-aragonite transition, reinvestigated. Contributions to Mineralogy and Petrology 31, 28-38.

Malaspina, N., Tumiati, S., 2012. The role of $\mathrm{COH}$ and oxygen fugacity in subduction-zone garnet peridotites. European Journal of Mineralogy 24, 607-618.

Manning, C.E., 2014. A piece of the deep carbon puzzle. Nature Geoscience 7, 333.

Marocchi, M., Hermann, J., Morten, L., 2007. Evidence for multi-stage metasomatism of chloriteamphibole peridotites (Ulten Zone, Italy): constraints from trace element compositions of hydrous phases. Lithos 99, 85-104.

Marocchi, M., Mair, V., Tropper, P., Bargossi, G.M., 2009. Metasomatic reaction bands at the Mt. Hochwart gneiss-peridotite contact (Ulten Zone, Italy): insights into fluid-rock interaction in subduction zones. Mineralogy and Petrology 95, 251-272.

Martin, S., Godard, G., Prosser, G., Schiavo, A., Bernoulli, D., Ranalli, G., 1998. Evolution of the deep crust at the junction Austroalpine/Southalpine: the Tonale Nappe. Memorie di Scienze Geologiche 50, 3-50.

Morten, L., Obata, M., 1990. Rare earth abundances in the eastern Alpine peridotites, Nonsberg area, Northern Italy. European Journal of Mineralogy 643-654.

Müller, W., Prosser, G., Mancktelow, N.S., Villa, I.M., Kelley, S.P., Viola, G., Oberli, F., 2001. Geochronological constraints on the evolution of the Periadriatic Fault System (Alps). International Journal of Earth Sciences 90, 623-653.

Nimis, P., Morten, L., 2000. P-T evolution of 'crustal' garnet peridotites and included pyroxenites from Nonsberg area (upper Austroalpine), NE Italy: from the wedge to the slab. Journal of Geodynamics 30, 93-115.

Obata, M., Morten, L., 1987. Transformation of spinel lherzolite to garnet lherzolite in ultramafic lenses of the Austridic crystalline complex, northern Italy. Journal of Petrology 28, 599623.

Petrini, R., and Morten, L., 1993. Nd-isotopic evidence of enriched lithospheric domains: an example from the Nonsberg area, Eastern Alps. Terra Nova 5, 19-20.

Rampone, E., Morten, L., 2001. Records of crustal metasomatism in the garnet peridotites of the Ulten Zone (Upper Austroalpine, Eastern Alps). Journal of Petrology 42, 207-219.

Ranalli, G., Martin, S., Mahatsente, R., 2005. Continental subduction and exhumation: an example from the Ulten Unit, Tonale Nappe, Eastern Austroalpine. Geological Society, London, Special Publications 243, 159-174.

Salters, V.J.M. and Stracke, A., 2004. Composition on the depleted mantle. Geochemistry Geophysics Geosystems 5, 1-27. 
Sapienza, G.T., Scambelluri, M., Braga, R., 2009. Dolomite-bearing orogenic garnet peridotites witness fluid-mediated carbon recycling in a mantle wedge (Ulten Zone, Eastern Alps, Italy). Contributions to Mineralogy and Petrology 158, 401-420.

Scambelluri, M., Hermann, J., Morten, L., Rampone, E., 2006. Melt-versus fluid-induced metasomatism in spinel to garnet wedge peridotites (Ulten Zone, Eastern Italian Alps): clues from trace element and $\mathrm{Li}$ abundances. Contributions to Mineralogy and Petrology 151, $372-394$.

Schramke, J.A., Kerrick D.M., Blencoe J.G., 1982. Experimental determination of the brucite $=$ periclase + water equilibrium with a new volumetric technique. American Mineralogist 67, 269-276.

Tumiati, S., Thöni, M., Nimis, P., Martin, S., Mair, V., 2003. Mantle-crust interactions during Variscan subduction in the Eastern Alps (Nonsberg-Ulten zone): geochronology and new petrological constraints. Earth and Planetary Science Letters 210, 509-526.

Tumiati, S., Godard, G., Martin, S., Klötzli, U., Monticelli, D., 2007. Fluid-controlled crustal metasomatism within a high-pressure subducted mélange (Mt. Hochwart, Eastern Italian Alps). Lithos 94, 148-167.

Tumiati, S., Fumagalli, P., Tiraboschi, C., Poli, S., 2013. An experimental study on COH-bearing peridotite up to $3.2 \mathrm{GPA}$ and implications for crust-mantle recycling. Journal of Petrology 54, 453-479.

Van Achterbergh, E., Ryan, C.,G., Jackson, S.E., Griffin, W.,L., Sylvester, P., 2001. LaserAblation-ICPMS in the Earth Sciences- Principles and Applications. Mineralogical Association of Canada. 239-243.

van Geldern, R., Joachimski M.M., Day, J., Jansen, U., Alvarez, F., Yolkin E.A., Ma, X.,-P., 2006. Carbon, oxygen and strontium isotope records of Devonian brachiopod shell calcite. Paleogeography, Palaeoclimatology, Palaeoecology 240, 47-67.

Weber, M., Lugli, F., Hattendorf, B., Scholz, D., Mertz-Kraus, R., Guinoiseau, D., Jochum, K.P. (2019) NanoSr-A - new carbonate microanalytical reference material for In situ Strontium isotope analysis. Geostandards and Geoanalytical Research doi.org/10.1111/ggr.12296.

Whitney, D.L., Evans, B.W., 2010. Abbreviations for names of rock-forming minerals. American Mineralogist 95, 185-187.

Zanetti, A., Mazzucchelli, M., Rivalenti, G., Vannucci, R., 1999. The Finero Phlogopite-Peridotite Massif: An example of subduction-related metasomatism. Contributions to Mineralogy and Petrology 134, 107-122.

Zheng, Y.-F., 2012. Metamorphic chemical geodynamics in continental subduction zones. Chemical Geology 328, 5-48.

Zheng, Y.-F., 2009. Fluid regime in continental subduction zones: petrological insights from ultrahigh-pressure metamorphic rocks. Journal of the Geological Society 166, 763-782.

\section{Figure captions - Preference color: online only}

Fig.1: Geological sketch map of the study area: localization of the Ulten Zone in the Northeastern

Alps and simplified geological map of the Ulten Zone from the 1:10.000 sheets Appiano and Rabbi

of the Italian Geological Map with samples localization. 
625 Fig. 2: $P-T$ trajectory of the Ulten Zone peridotites. Infiltration of hot deep melt (red oval) into 626 wedge peridotites in the spinel stage (Stage1); downward flow of wedge peridotites close to the 627 slab-wedge interface due to corner flow (Stage2); exhumation after incorporation of peridotites in a 628 crust-mantle mélange (Stage 3). Redrawn after Nimis and Morten (2000) and Scambelluri et al. 629 (2006).

630 Fig.3: The Ulten Zone peridotites in the field. (a) Overview of the geological setting close to Malga 631 Masa Murada with indication of the peridotites outcrop showed in detail in (b); (c)-(d)

632 Serpentinized fine-grained peridotites; (e) Highly altered coarse-grained peridotite with coarse 633 orthopyroxenes.

634 Fig.4: Overview of (a) Coarse-grained spinel peridotite MOL1-C with its characteristic serpentine + 635 magnesite + tremolite vein. See text for detailed description. (b) Fine-grained porphyroblastic636 garnet-bearing peridotite KL2.4-3. Pinkish-garnet is surrounded by keliphytic corona and includes 637 larges spinels with polycrystalline aggregates. In this peridotite serpentine is common, in 638 association with magnetite. (c) Fine-grained garnet-bearing peridotite KL1-A. Mineral 639 abbreviations after Whitney and Evans (2010).

640 Fig.5: BSE images of carbonates from the Ulten Zone peridotite. (a) 18LP1. Lobate-shaped 641 dolomite grains constituting a veinlet with tremolite and chlorite; (b)18LP1. Dolomite streaks into 642 serpentine vein; (c) MOL1-C. Serpentine vein with magnesite and tremolitic amphibole. Infiltration 643 of the vein into orthopyroxene formed spectacular needle-shaped microstructure with opaque 644 minerals; (d) MOL1-C. Dolomite vein cutting the magnesite veinlet; (e) VM10A. Interstitial 645 dolomite with its perfect cleavage; (f) KL1-A. Matrix dolomite associated with apatite. Note the 646 incipient formation of calcite-brucite intergrowths into dolomite; (g) KL2.4-3. Large spinel cut by a 
Fig.6: Carbonates composition plotted in the $\mathrm{MgCO}_{3}-\mathrm{CaCO}_{3}-\mathrm{FeCO}_{3}$ ternary diagram.

thin calcite vein; (h) MM1. Matrix dolomite (with little magnesite inclusions) associated with apatite and serpentine. Mineral abbreviations after Whitney and Evans (2010).
650

651

Fig.7: BSE image of calcite-brucite intergrowths occurring in fine-grained garnet-amphibole peridotite KL1-A. The stars point out the spots for micro-Raman analyses whose spectra is reported in Fig.9. The yellow arrows indicate the serpentine surrounding calcite-brucite intergrowths. Mineral abbreviations after Whitney and Evans (2010).

Fig.8: Sr isotope ratios for dolomites and calcites occurring in different microstructural positions measured by LA-MC-ICP-MS. The error bars represent \pm 2 standard errors. Whole rock ${ }^{87} \mathrm{Sr} /{ }^{86} \mathrm{Sr}$ for fine-grained garnet-amphibole peridotite A4323 and coarse-grained spinel-garnet peridotite A4454 from the work of Tumiati et al. (2003) are reported for comparison.

Fig.9: Partial sketch of a dolomite vein associated with tremolite and chlorite in sample 18LP1 with SEM-BSE images associated. Analyzed spots with Sr isotope ratio are reported.

Fig. 10: $P-T$ diagram with stages of carbonates formation during the metasomatic evolution of the Ulten peridotites. See text for discussion. Reference curves: Dolomite-in, magnesite-in, dolomiteout, garnet-in curve from Tumiati et al., (2013); tremolite $(\mathrm{Tr})+$ magnesite $(\mathrm{Mgs})=$ enstatite $(\mathrm{En})+$ dolomite (Dol) from Malaspina and Tumiati (2012) for $\mathrm{X}_{\mathrm{CO} 2}=0.5$; brucite $(\mathrm{Brc})=$ periclase $($ Per $)+$ water $\left(\mathrm{H}_{2} \mathrm{O}\right)$ from Schramke et al., (1982). Antigorite-out curve and chlorite-out curve from Fumagalli and Poli (2005). Antigorite = chrysotile (Ctl) / Lizardite (Liz) from Evans (1976); aragonite $=$ calcite from Johannes and Puhan (1971). The HP-garnet stage and chlorite-amphibole 
667 stage correspond to the thermobarometric data obtained by Nimis and Morten (2000) and Sapienza 668 et al. (2009). Mineral abbreviations after Whitney and Evans (2010).

669 Fig.11: Strontium isotopic compositions of carbonates from the Ulten Zone peridotites in 670 comparison with the potential sources of C-bearing fluids. MORB values taken from Salters and 671 Stracke (2004); the Sr-isotope values of stromatic gneisses and peridotites from Tumiati et al. 672 (2003) and the stromatic gneisses, orthogneisses and trondhjemitic intrusions from Del Moro et al. 673 (1999) are recalculated for $\mathrm{t}=330 \mathrm{Ma}$, corresponding to the inferred age of the last isotopic 674 homogenization event. The Sr-isotope values for the brachiopod shell calcites from van Geldern et 675 al. (2006) correspond to Early to Late Devonian (Emsian-Eifelian boundary and early Famennian). 
Fig.1

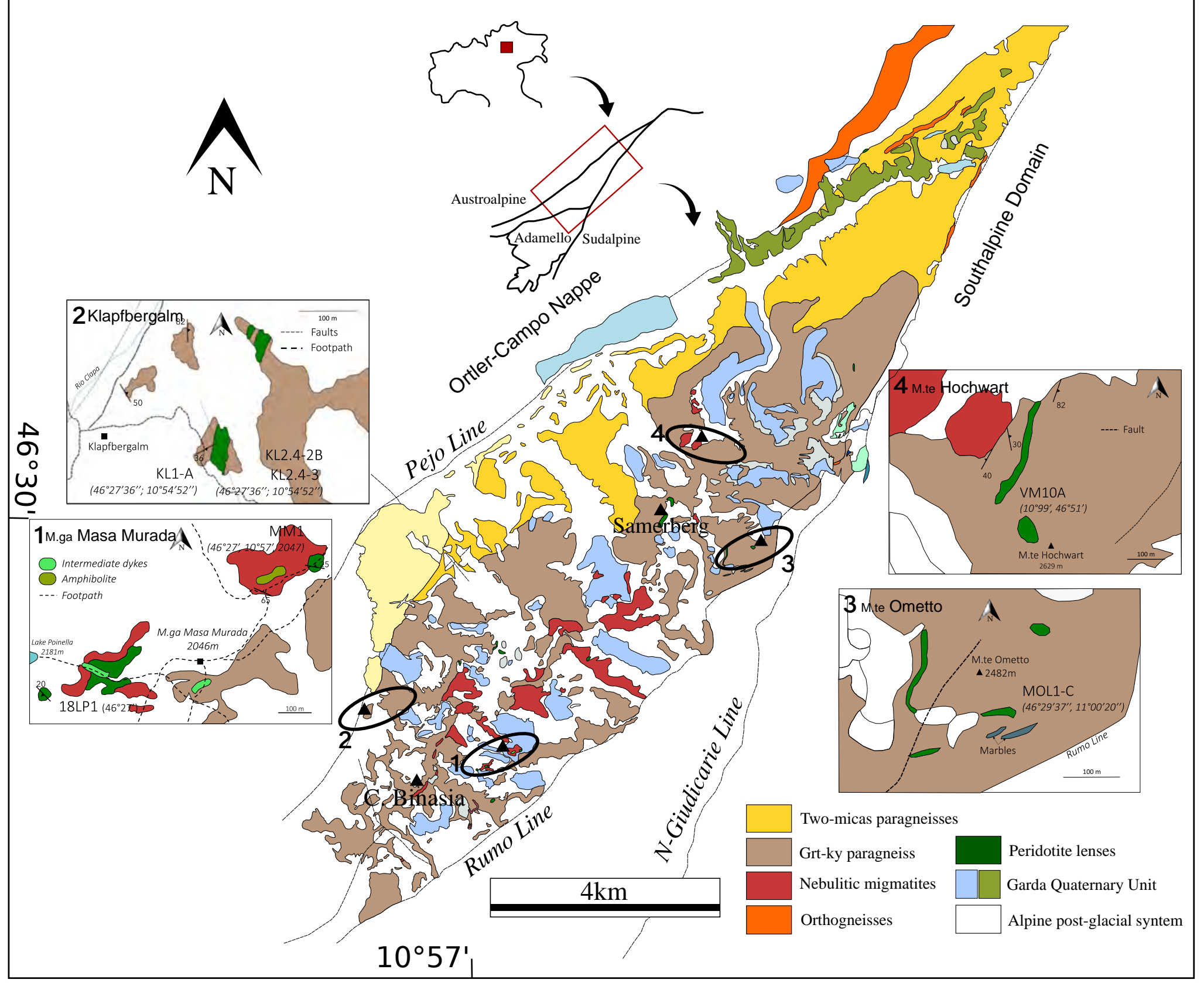




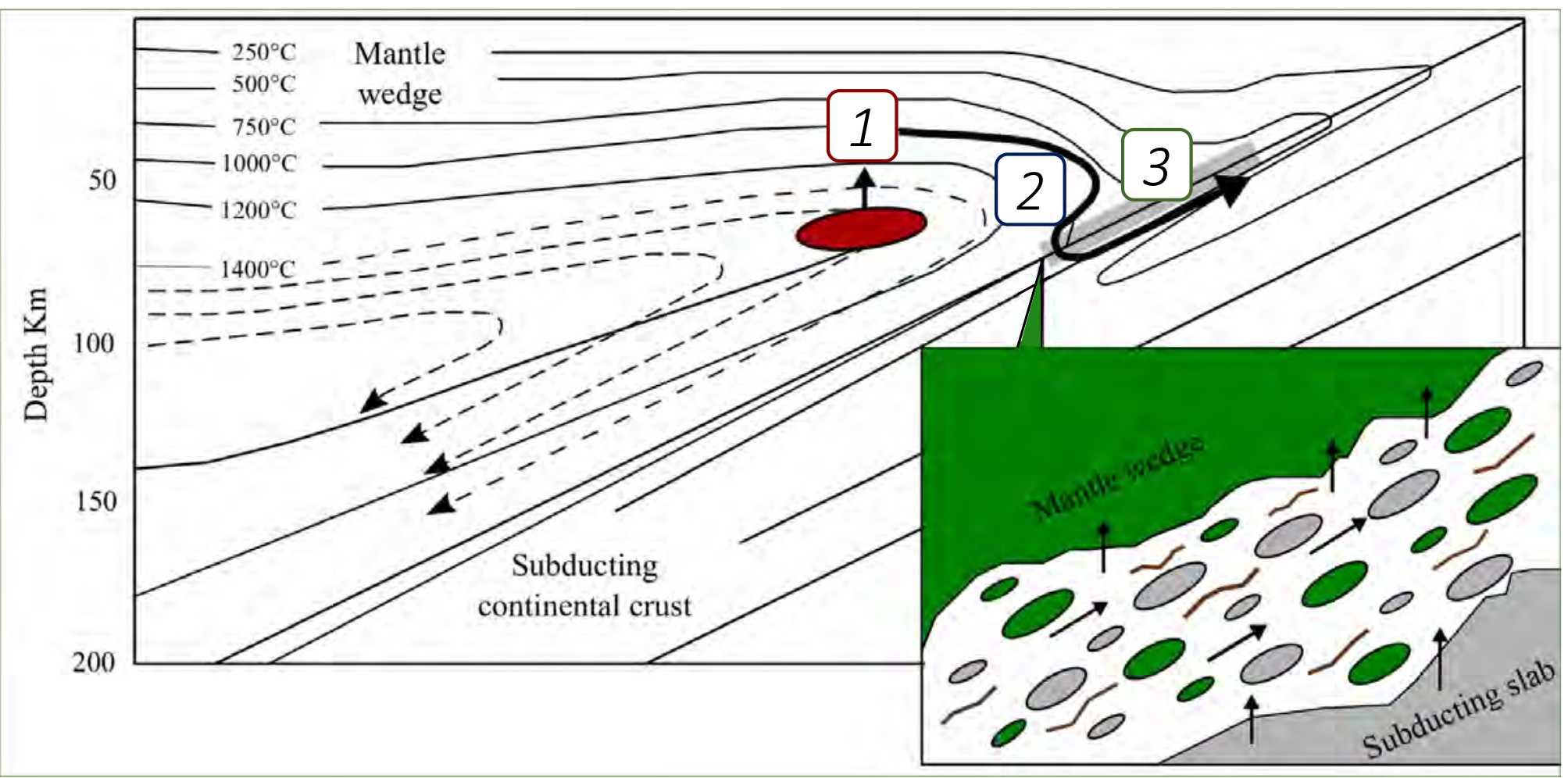



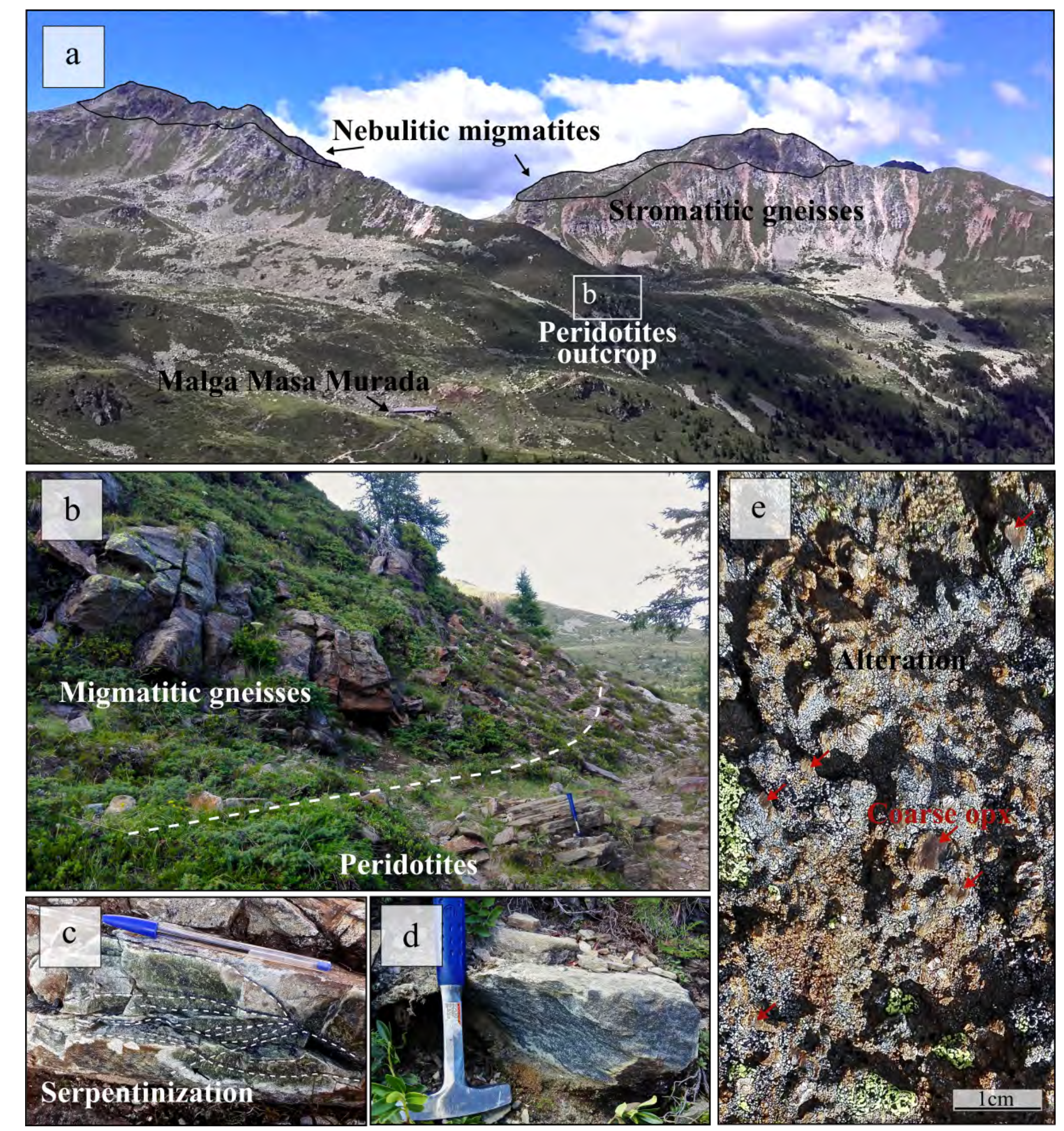

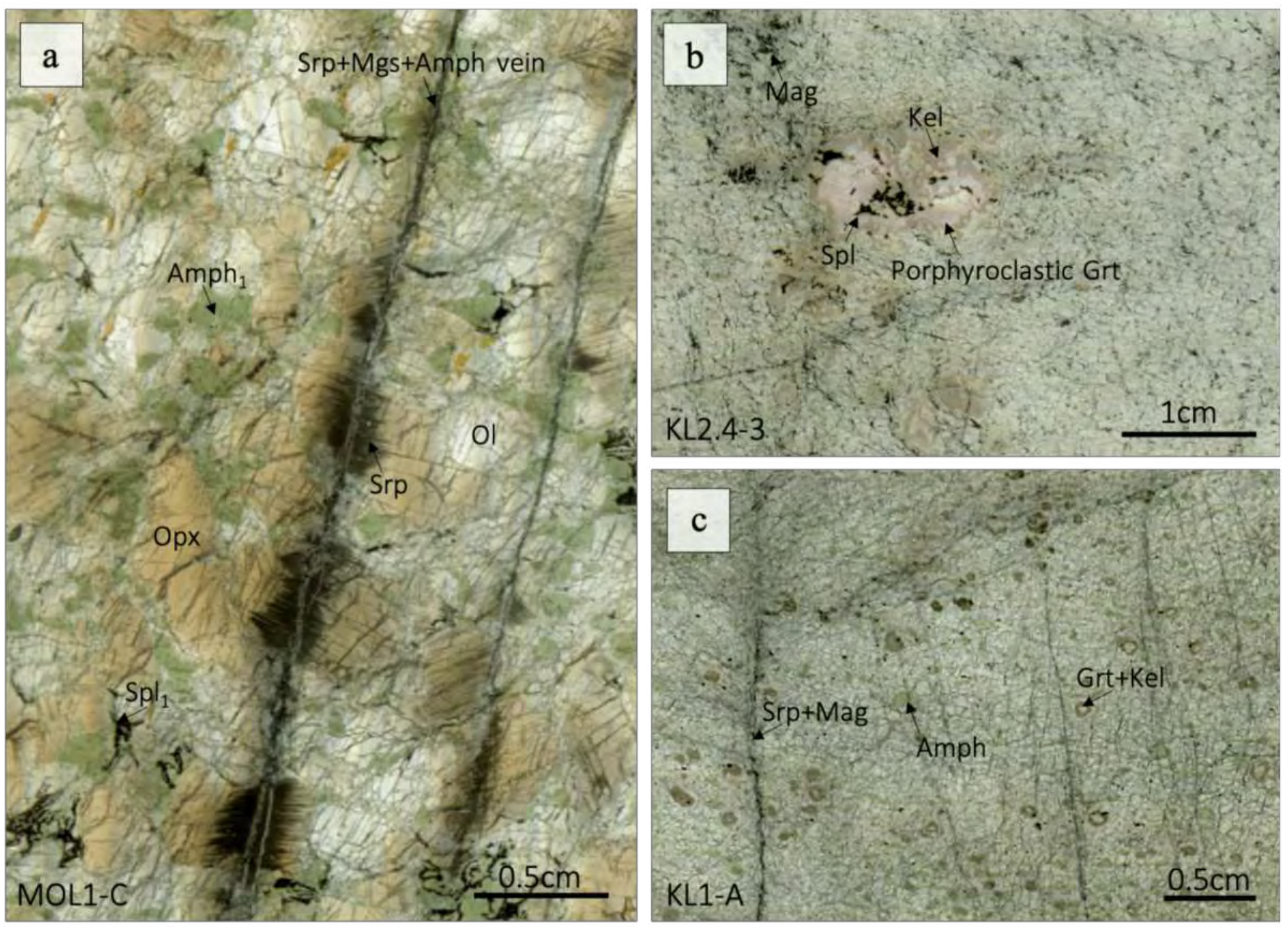


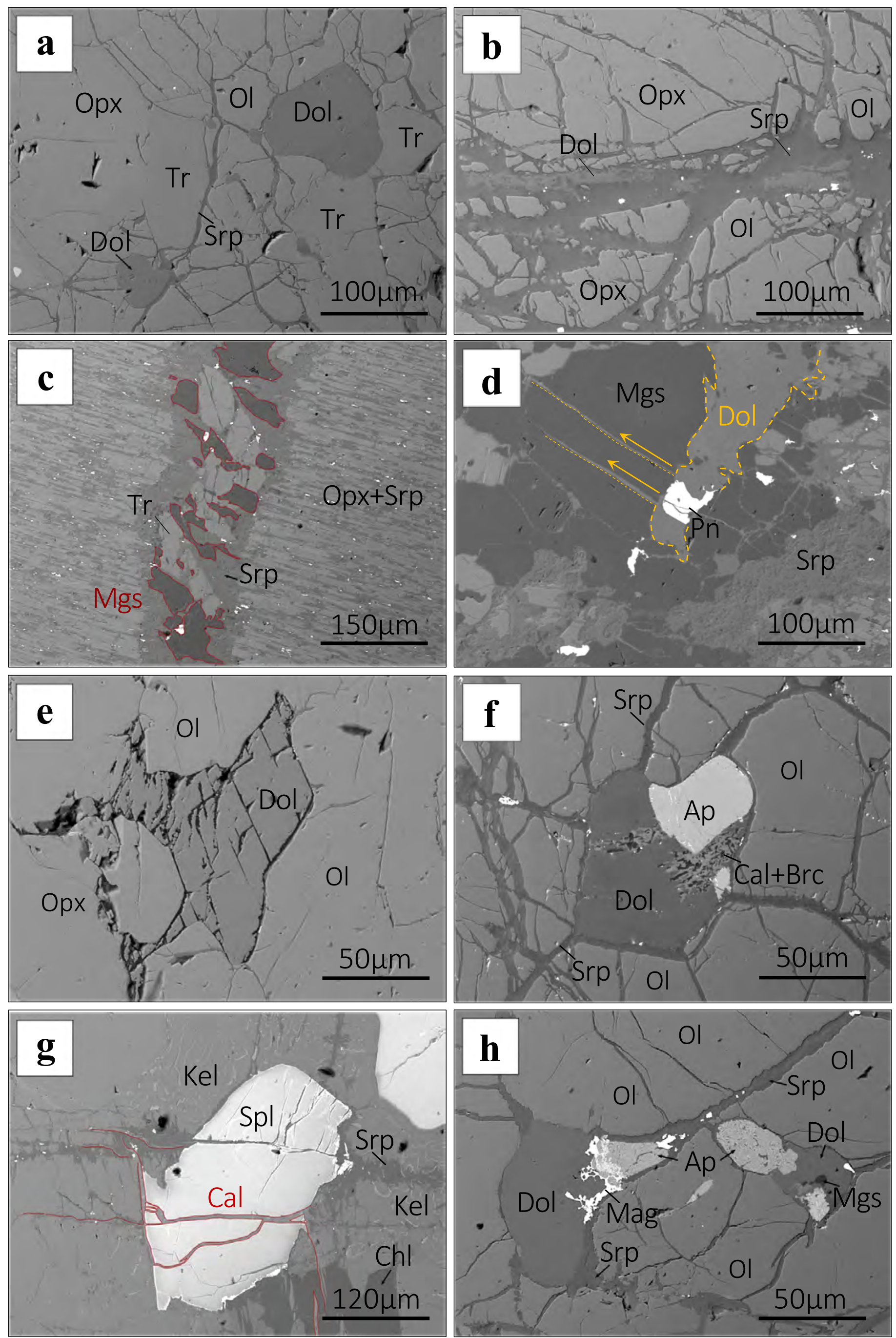




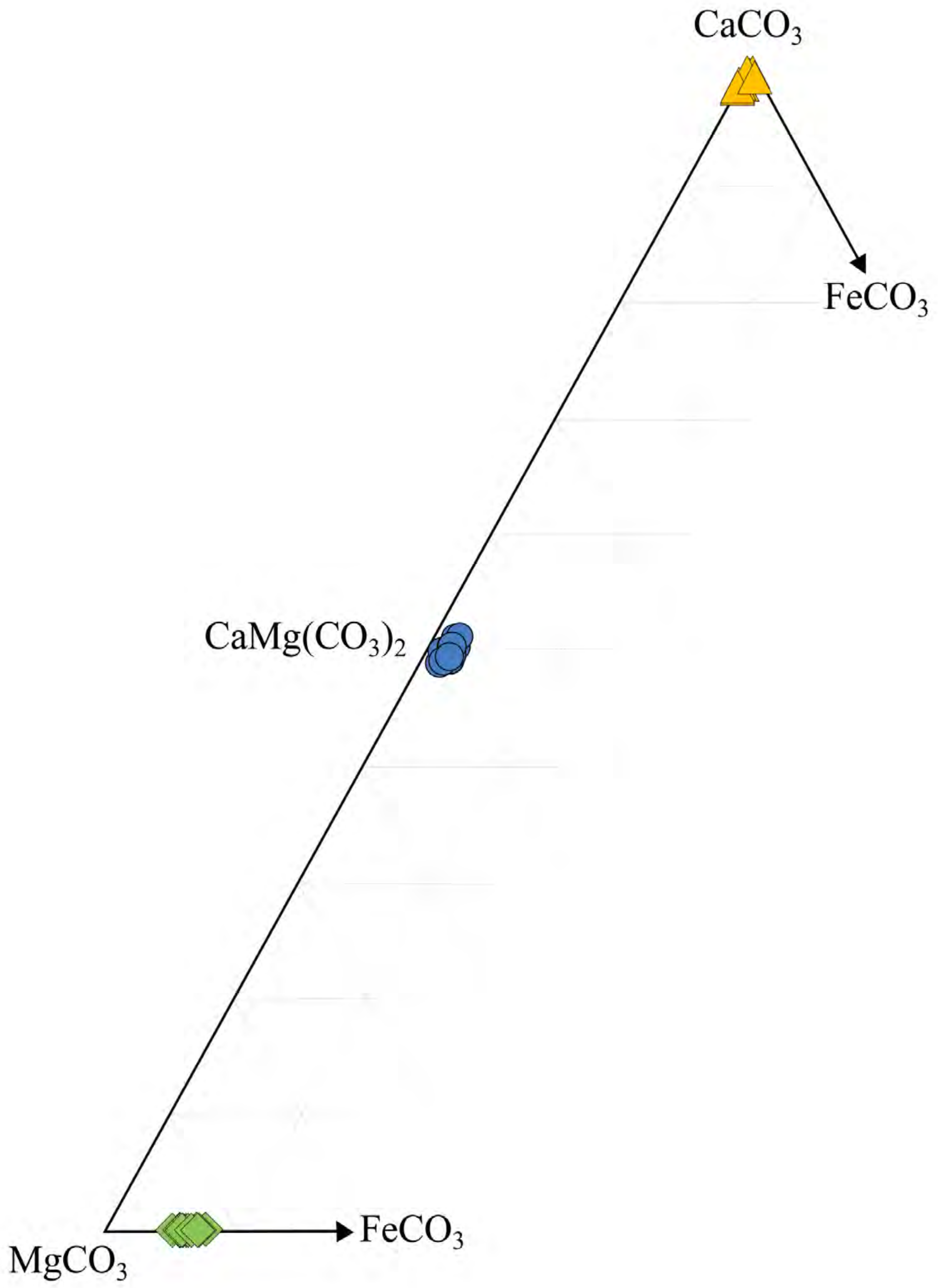




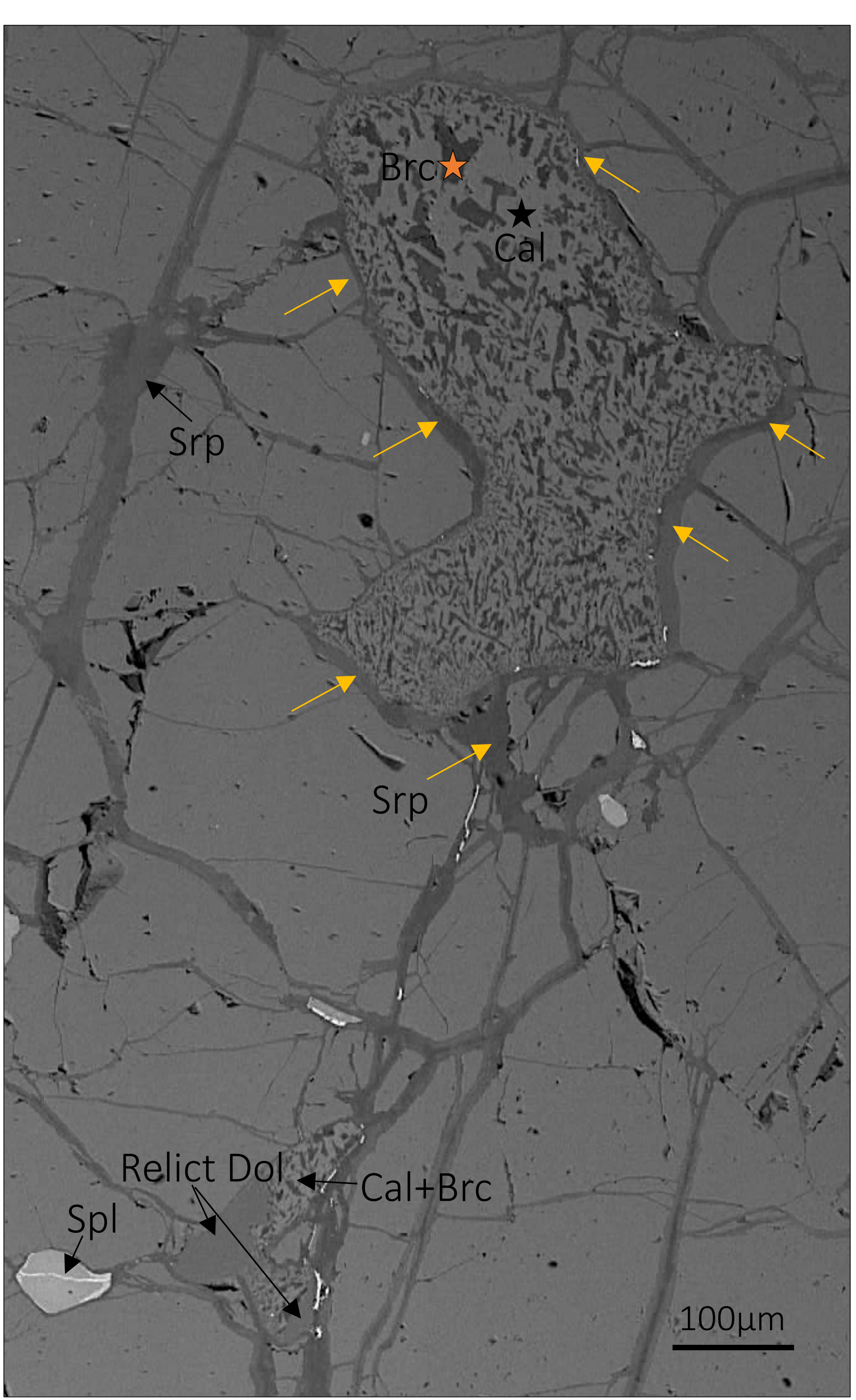




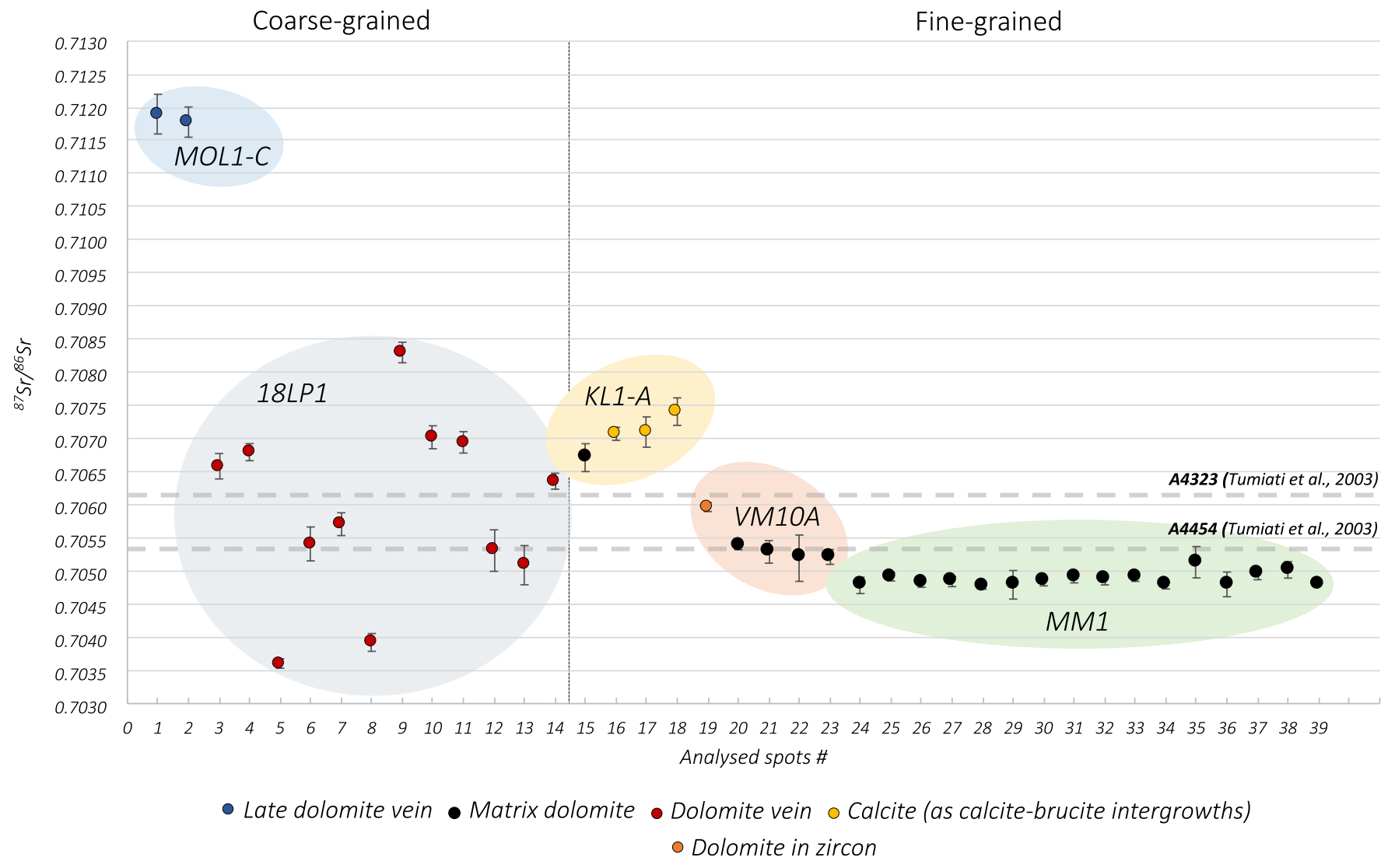


Figure9

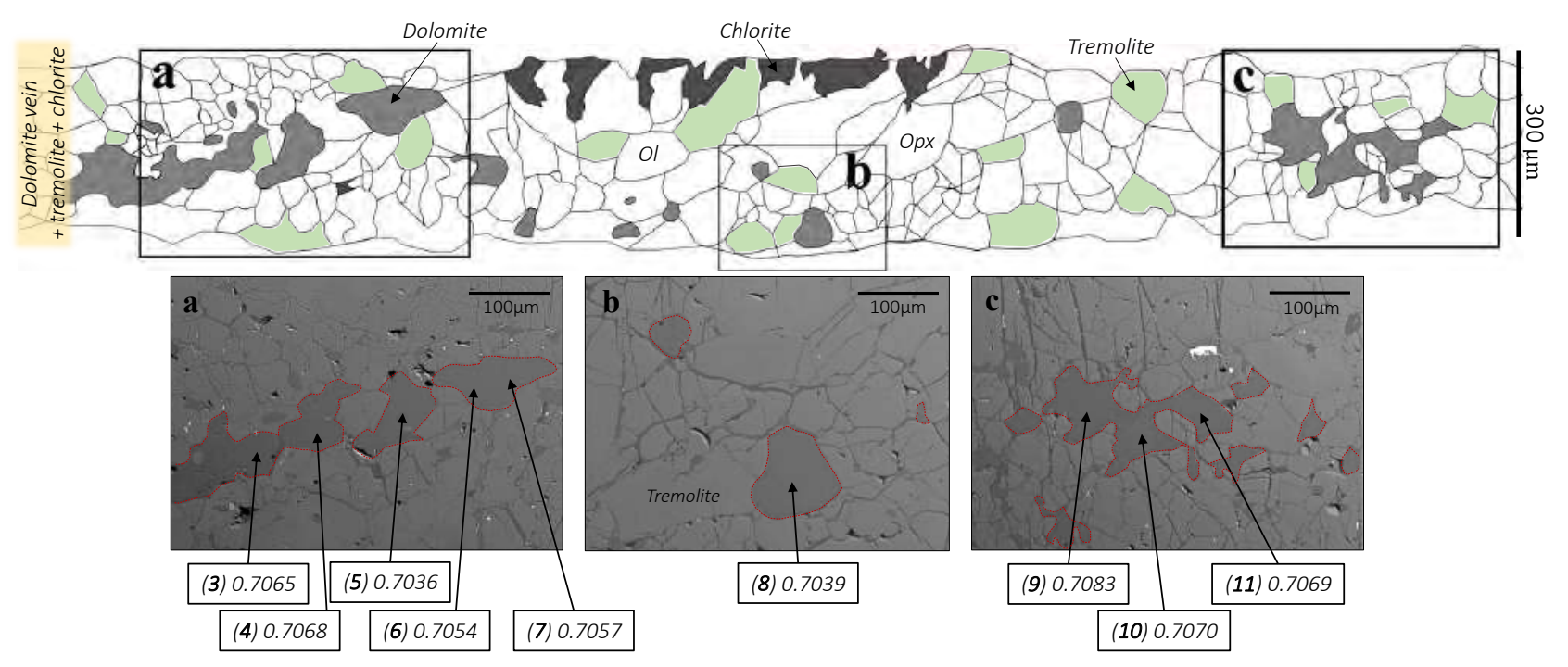




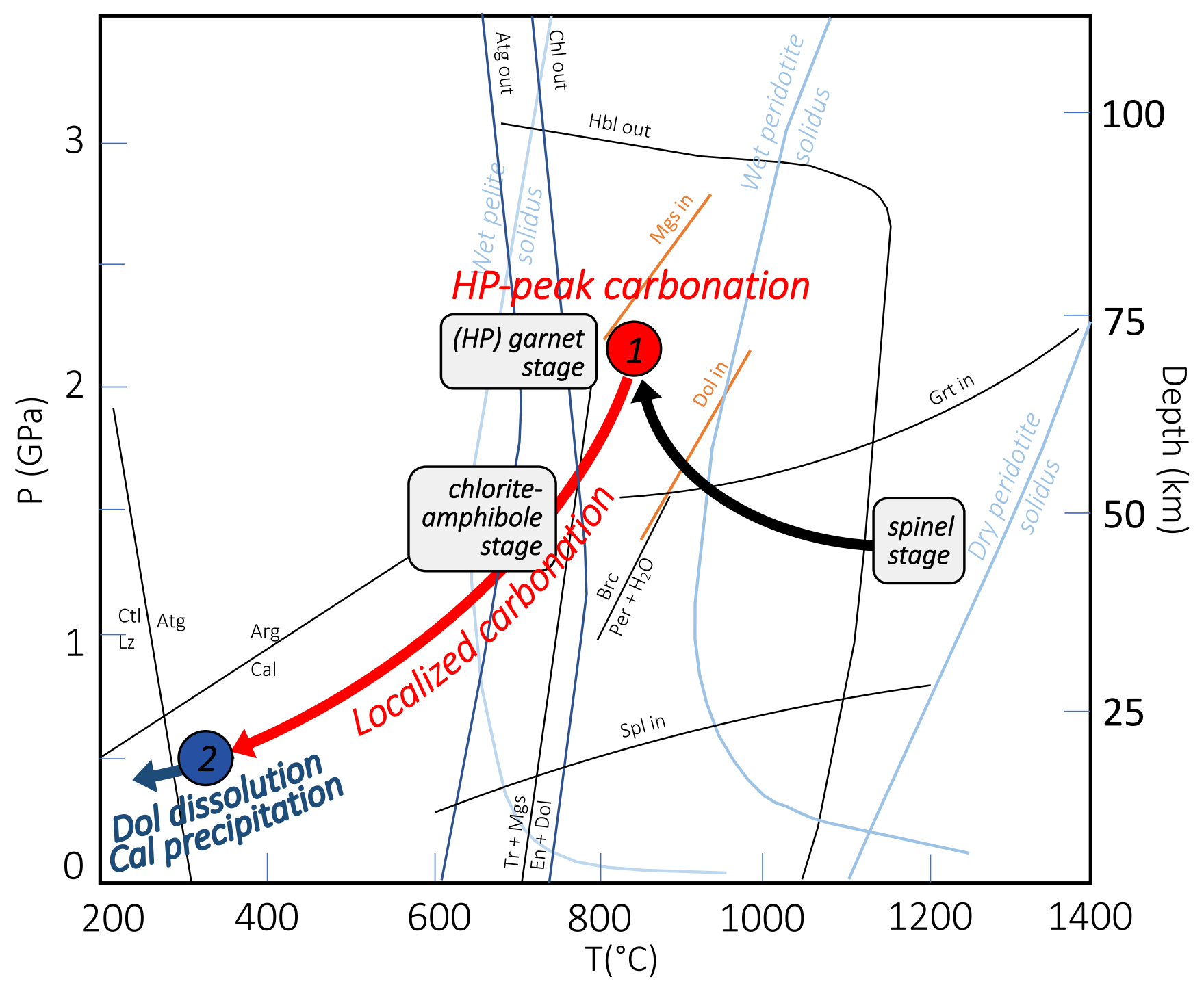




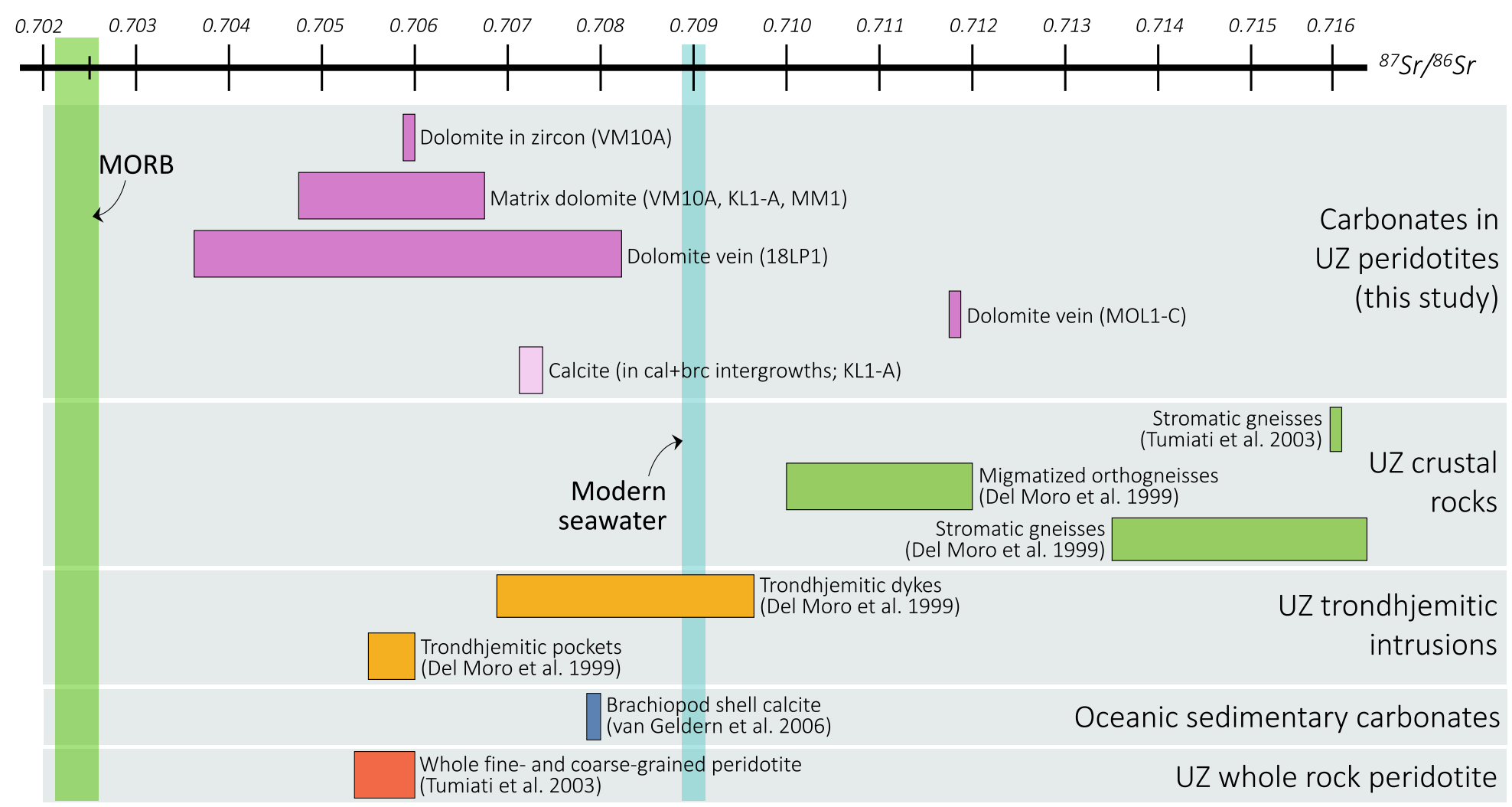


Supplementary Materials - Figures

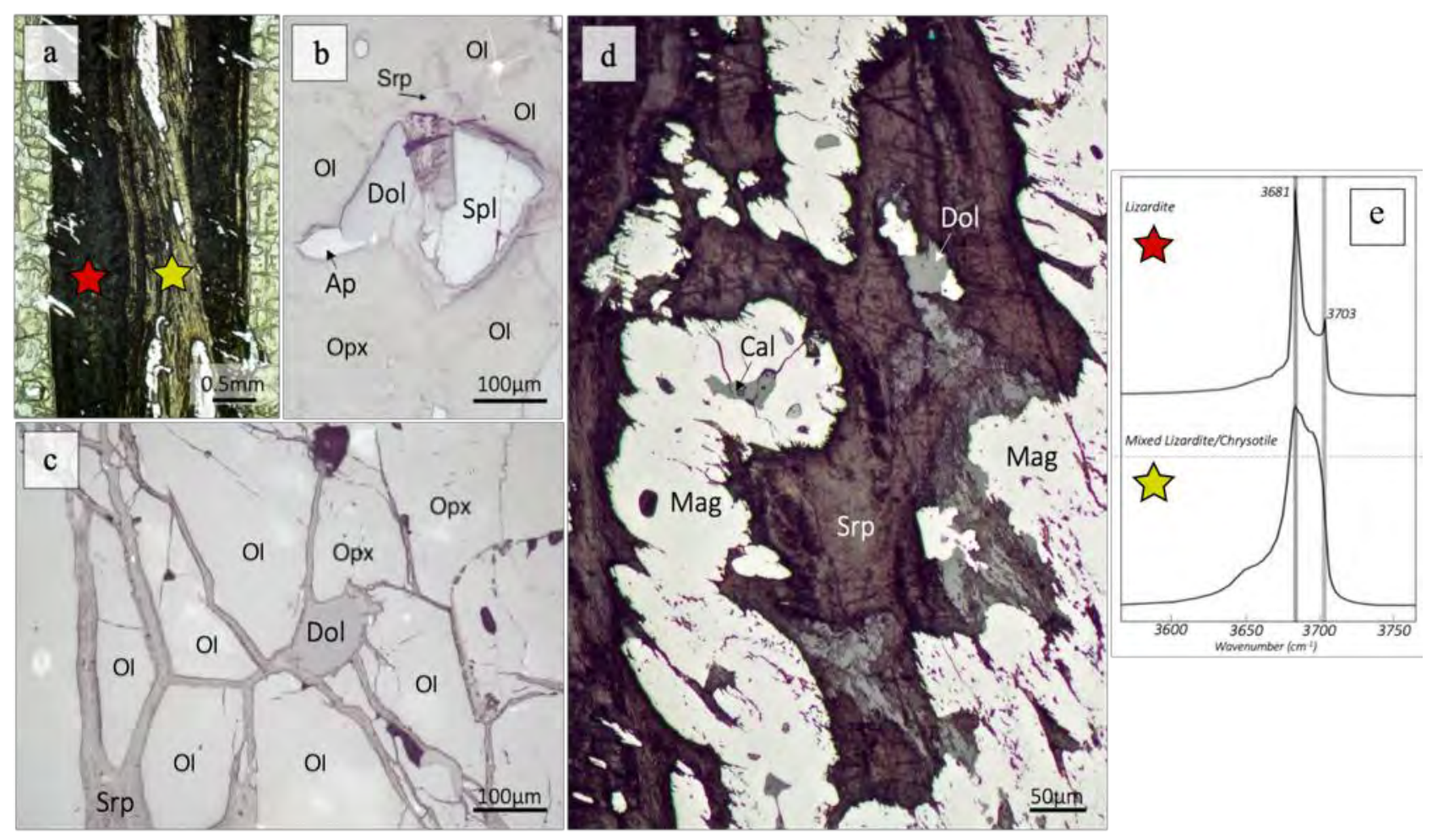

Fig. S1

(a) Zoned serpentine-rich vein cutting the MM1 fine-grained amphibole-chlorite peridotite with its constituting minerals under optical reflected light (b)-(c)-(d). (b) Matrix dolomite associated with $\mathrm{Cl}$-apatite and spinel. (c) Matrix dolomite surrounded by serpentine. (d) Vein core consisting of serpentine + magnetite with calcite and dolomite included; (e) Micro-Raman spectra acquired in the $\mathrm{OH}$ region for a composite serpentine vein. Stars represent the analyzed spots. Mineral abbreviations after Whitney and Evans (2010). 


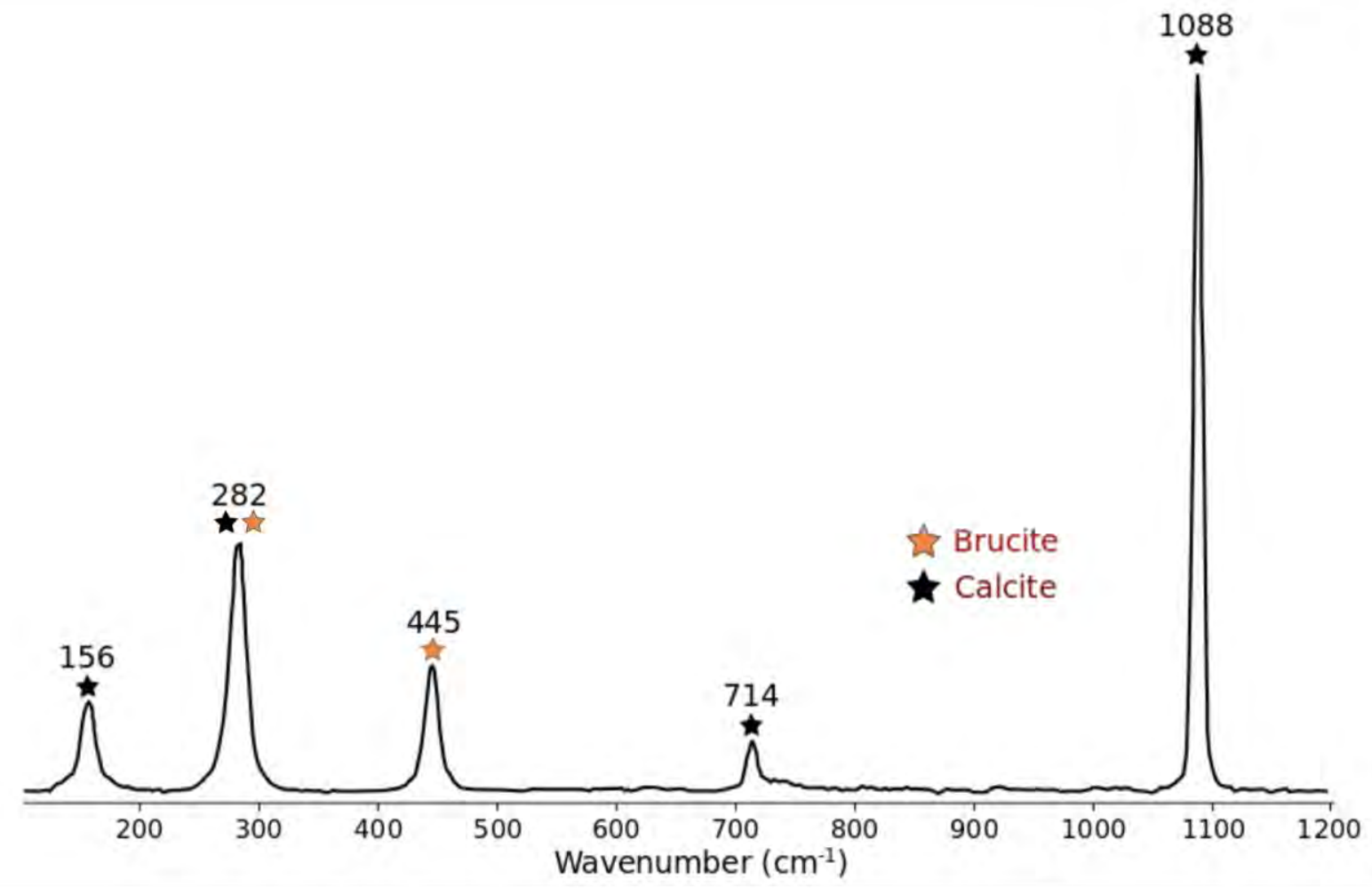

Fig. S2

Micro-Raman spectrum of analyzed calcite and brucite. 
Table1. Studied samples from the Ulten Zone.

\begin{tabular}{|c|c|c|c|c|c|c|c|c|}
\hline 18LP1 & $\begin{array}{l}\text { Cima } \\
\text { Binasia } \\
\text { nearby } \\
\text { Lavazze } \\
\text { river (as } \\
\text { sample LP6; } \\
\text { Ionov et al., } \\
2017 \text { ) }\end{array}$ & $\mathrm{Sp}$ & Coarse & $\begin{array}{l}\mathrm{Ol}_{1}+\mathrm{Opx}_{1}+ \\
\mathrm{Amph}+\mathrm{Spl}_{1}+ \\
\mathrm{Cpx}_{\mathrm{I}}+\mathrm{Dol}+\mathrm{Chl} \\
+\mathrm{Phl}+\mathrm{Op}\end{array}$ & $\begin{array}{l}\text { Dolomite veinlet (ca. } \\
300 \mu \mathrm{m} \text { wide) cut by } \\
\text { thin serpentine veins } \\
\text { with dolomite vein } \\
\text { included (ca. } 25 \mu \mathrm{m} \\
\text { wide). Abundance: < } \\
1 \%\end{array}$ & Medium & Chip & $X$ \\
\hline MOL1-C & M.te Ometto & $\mathrm{Sp}$ & Coarse & $\begin{array}{l}\mathrm{Ol}_{1}+\mathrm{Opx}_{1}+ \\
\mathrm{Amph}+\mathrm{Spl}_{1}+ \\
\mathrm{Mgs}+\mathrm{Srp}+\mathrm{Chl} \\
+\mathrm{Phl}+\mathrm{Op}\end{array}$ & $\begin{array}{l}\text { Magnesite vein (ca. } \\
300 \mu \mathrm{m} \text { wide) cut by } \\
\text { late dolomite vein } \\
\text { (ca. } 200 \mu \mathrm{m} \text { long). }\end{array}$ & Medium & $\begin{array}{l}\text { Thick } \\
\text { section }\end{array}$ & $X$ \\
\hline K|L1-A & $\begin{array}{l}\text { Klapfbergal } \\
\mathrm{m}\end{array}$ & Grt & Fine & $\begin{array}{l}\mathrm{Ol}_{2}+\mathrm{Opx}_{2}+ \\
\mathrm{Spl}_{2}+\mathrm{Grt}_{2}+\mathrm{Srp} \\
+\mathrm{Op}\end{array}$ & $\begin{array}{l}\text { Calcite plus brucite } \\
\text { aggregates; matrix } \\
\text { dolomite (ca. } 50 \\
\mu \mathrm{m}) \text {. Abundance }:<1 \\
\% \text {. }\end{array}$ & High & $\begin{array}{l}\text { Thick } \\
\text { section } \\
\text { Chip }\end{array}$ & $\mathrm{X}$ \\
\hline $\begin{array}{l}\text { KL2.4-2b } \\
\text { KL2.4-3 }\end{array}$ & $\begin{array}{l}\text { Klapfbergal } \\
\mathrm{m}\end{array}$ & Grt & $\begin{array}{c}\text { Porphyroblast } \\
\text { ic }\end{array}$ & $\begin{array}{l}\mathrm{Ol}_{2}+\mathrm{Opx}_{2}+ \\
\mathrm{Spl}_{2}+\mathrm{Grt}_{2}+ \\
\mathrm{Amph}+\mathrm{Srp}+ \\
\mathrm{Dol}+\mathrm{Cal}+\mathrm{Op}\end{array}$ & $\begin{array}{l}\text { Dolomite inclusion } \\
(\text { ca. } 70 \mu \mathrm{m}) \text { in a } \\
\text { primary } \text { spinel,; } \\
\text { calcite plus brucite } \\
\text { intergrowths }(<1 \%) \text {. }\end{array}$ & High & $\begin{array}{l}\text { Thick } \\
\text { section }\end{array}$ & \\
\hline
\end{tabular}

Mineral abbreviation after Whitney and Evans, (2010) 
Table 2. Main representative major elements compositions of minerals measured by EPM.

\begin{tabular}{|c|c|c|c|c|c|c|c|c|c|c|c|c|c|}
\hline Mineral & Olivine & & & Enstatite & & & Diopside & & & Amphi & & & \\
\hline $\begin{array}{l}\text { M-type } \\
\text { sample }\end{array}$ & $\mathrm{C}$ & & $F$ & C & & $F$ & $\mathrm{C}$ & $F$ & & C & $\mathrm{F}$ & C & \\
\hline Generation & I & II & I & I & II & II & I & II & & & & & \\
\hline Comment & $\mathrm{m}$ & $\mathrm{m}$ & $\mathrm{m}$ & m & $\mathrm{m}$ & $\mathrm{m}$ & $\mathrm{m}$ & $\mathrm{m}$ & $\begin{array}{l}\text { Relic in } \\
\text { amph }\end{array}$ & $\mathrm{m}$ & m & $\begin{array}{l}\text { In } \\
\text { mgs } \\
\text { vein }\end{array}$ & $\begin{array}{c}\text { In } \\
\text { dol+chl+tr } \\
\text { vein }\end{array}$ \\
\hline $\mathrm{SiO}_{2}$ & 40.89 & 40.92 & 40.80 & 55.96 & 56.30 & 56.94 & 53.84 & 54.33 & 54.00 & 46.76 & 45.51 & 57.26 & 57.43 \\
\hline $\mathbf{A l}_{2} \mathrm{O}_{3}$ & bdl & bdl & bdl & 2.80 & 2.51 & 1.40 & 1.41 & 1.27 & 1.01 & 10.88 & 12.01 & 1.32 & 0.91 \\
\hline MgO & 49.72 & 49.04 & 49.23 & 33.80 & 33.84 & 34.61 & 17.01 & 17.22 & 17.47 & 19.20 & 18.33 & 23.20 & 23.40 \\
\hline $\mathrm{CaO}$ & bdl & bdl & bdl & 0.27 & 0.32 & 0.18 & 24.78 & 24.83 & 24.23 & 12.06 & 12.37 & 12.86 & 12.92 \\
\hline $\mathbf{K}_{2} \mathbf{O}$ & bdl & bdl & bdl & bdl & bdl & 0.01 & bdl & bdl & bdl & 0.15 & 0.55 & bdl & bdl \\
\hline $\mathbf{T i O}_{2}$ & bdl & bdl & bdl & bdl & bdl & bødl & 0.05 & bdl & 0.12 & 0.21 & 0.48 & bdl & bdl \\
\hline $\mathrm{FeO}$ & 9.57 & 9.51 & 9.37 & 6.33 & 6.40 & 6.29 & 1.56 & 1.81 & 1.70 & 3.07 & 2.81 & 2.09 & 1.70 \\
\hline MnO & 0.14 & 0.15 & 0.12 & 0.19 & 0.11 & 0.15 & 0.07 & 0.06 & bdl & bøbdl & bdl & 0.10 & bdl \\
\hline $\mathrm{Cr}_{2} \mathrm{O}_{3}$ & bdl & bdl & bdl & 0.26 & 0.17 & 0.18 & 0.38 & 0.25 & 0.29 & 0.85 & 1.67 & 0.16 & 0.26 \\
\hline $\mathrm{Na}_{2} \mathrm{O}$ & bdl & bdl & bdl & bdl & bdl & bøddl & 0.22 & 0.22 & 0.23 & 2.39 & 1.95 & 0.37 & 0.19 \\
\hline NiO & 0.41 & 0.37 & 0.40 & bdl & 0.11 & 0.02 & bdl & bdl & bdl & bdl & bdl & 0.06 & 0.07 \\
\hline Sum & $\begin{array}{c}100.7 \\
2\end{array}$ & 100.06 & 99.95 & 99.70 & 99.81 & 99.76 & 99.58 & 100.18 & 99.05 & 95.57 & 95.68 & 97.36 & 96.95 \\
\hline Si & $\frac{1.000}{995}$ & $1.00 z$ & 1.000 .997 & 1.9437 & $\frac{1.954}{7}$ & 1.953 & 1.9766 & $1.97 \pm$ & $1.9 \underline{8} 76$ & 6.642 & 6.513 & 7.8218 & $7.88 \theta$ \\
\hline Ti & & & & & & & $0.00+$ & $0.00 z$ & 0.003 & & $0.05+$ & & \\
\hline Al & & & & 0.114 & & & & 0.054 & 0.044 & $1.3 \underline{6} 58$ & $2.0 \underline{3} 26$ & $1.82 z$ & $0.1 \underline{1} 47$ \\
\hline $\mathrm{Cr}$ & & & & 0.0107 & $\frac{0.01 \theta}{5}$ & 0.0105 & $0.01+$ & 0.0107 & 0.0108 & $0 . \frac{1009}{5}$ & 0.1289 & 0.0217 & $0.0 \underline{3} 28$ \\
\hline $\mathrm{Fe}^{3+}$ & $0.00 \theta$ & 0.000 & $0.0 \ominus 0$ & $0.00 \theta$ & & $0.00 \theta$ & $0.00 \theta$ & $0.00 \theta$ & $0.00 \theta$ & 0.344 & $0.2 \underline{8} 76$ & $0.22 z$ & 0.1107 \\
\hline $\mathrm{Fe}^{2+}$ & $\frac{0.201}{95}$ & $0 . \frac{2019}{5}$ & 1.90898 & 0.183 & $\frac{0.198}{5}$ & $0.18 z$ & $0.0 \underline{5} 48$ & $0.0 \underline{5} 55$ & $0.05 z$ & $0.02 \theta$ & $0.06+$ & 0.0716 & 0.0288 \\
\hline Mn & 0.003 & 0.003 & 0.003 & 0.0106 & 0.003 & 0.004 & $0.00 z$ & $0.00 z$ & & & & $0.01+$ & \\
\hline Mg & 1.804 & $1.79 \theta$ & 1.8105 & 1.744 & 1.744 & $1.78 z$ & $0.9 \underline{3} 26$ & $0.93+$ & 0.953 & 4.0166 & $3.91 t$ & 4.0766 & 4.7287 \\
\hline $\mathrm{Ca}$ & & & & $0.01 \theta$ & $0.01 z$ & 0.0106 & 0.9769 & 0.9765 & $0.95 \theta$ & 1.8436 & $1 . \frac{9089}{7}$ & 1.8436 & 1.90899 \\
\hline Sum & $\frac{3.01 \theta}{5}$ & 3.003 & 3.004 & 4.0109 & $\frac{4.01 \theta}{7}$ & 4.003 & 4.0109 & 4.0107 & 4.003 & $\begin{array}{c}10.5 \underline{5} 4 \\
7\end{array}$ & 10.564 & $\begin{array}{c}10.01 \theta \\
5\end{array}$ & 10.00 \\
\hline Mg\# & 0.90 & 0.90 & 0.90 & 0.91 & 0.90 & 0.91 & 0.95 & 0.95 & 0.95 & 1.00 & 0.98 & 1.00 & 0.96 \\
\hline
\end{tabular}

Olivine, enstatite and diopside generations are labeled I and II based on their composition and texture (see text for details); $C$ coarse grained; $F$ fine grained; $m$ mineral in the matrix; $P$ porphyroclast; In P-grt included in a porphyroblastic garnet; $m e s h$ mesh structure; $B d l$ below detection limit. 
Table2. Continued

\begin{tabular}{|c|c|c|c|c|c|c|c|c|c|c|c|c|c|c|}
\hline \multirow{4}{*}{$\begin{array}{l}\text { Mineral } \\
\text { M-type } \\
\text { sample } \\
\text { Generation } \\
\text { Comment }\end{array}$} & \multirow{2}{*}{\multicolumn{2}{|c|}{$\begin{array}{l}\text { Pyrope } \\
\text { F }\end{array}$}} & \multicolumn{4}{|c|}{ Cr-Spinel } & \multicolumn{3}{|c|}{ Lizardite } & \multicolumn{2}{|l|}{ Chlorite } & \multirow{2}{*}{\multicolumn{2}{|c|}{$\begin{array}{l}\text { Phlogopite } \\
\text { C }\end{array}$}} & \multirow{2}{*}{$\begin{array}{ll}\text { Apatite } \\
\text { F }\end{array}$} \\
\hline & & & \multicolumn{2}{|l|}{$\mathrm{C}$} & \multicolumn{2}{|l|}{$\mathrm{F}$} & \multirow[t]{2}{*}{$\mathrm{C}$} & \multicolumn{2}{|l|}{$\mathrm{F}$} & \multirow[t]{2}{*}{$\mathrm{C}$} & \multirow[t]{2}{*}{$\mathrm{F}$} & & & \\
\hline & I & II & I & II & I & II & & & & & & & & \\
\hline & $\mathrm{P}$ & $\mathrm{m}$ & $\mathrm{m}$ & $\mathrm{m}$ & $\begin{array}{c}\text { In P- } \\
\text { grt }\end{array}$ & $\mathrm{m}$ & vein & mesh & vein & $\begin{array}{c}\text { In } \\
\text { dol+chl+tr } \\
\text { vein }\end{array}$ & $\mathrm{m}$ & $\mathrm{m}$ & $\mathrm{m}$ & $\mathrm{m}$ \\
\hline $\mathrm{SiO}_{2}$ & 41.98 & 41.82 & bdl & 0.08 & bdl & 0.052 & 41.25 & 40.02 & 42.05 & 30.38 & 29.85 & 40.19 & 37.04 & bdl \\
\hline $\mathrm{Al}_{2} \mathrm{O}_{3}$ & $22 . .6$ & 22.12 & 45.43 & 26.47 & 30.67 & 37.73 & 0.34 & 0.49 & 0.13 & 19.08 & 20.04 & 14.63 & 15.07 & - \\
\hline $\mathrm{MgO}$ & 19.03 & 18.63 & 16.13 & 8.95 & 9.46 & 13.93 & 40.41 & 39.89 & 39.53 & 31.65 & 32.16 & 25.53 & 28.32 & bdl \\
\hline $\mathrm{CaO}$ & 5.38 & 5.63 & & - & - & - & bdl & bdl & bdl & 0.04 & bdl & bdl & bdl & 53.45 \\
\hline $\mathbf{K}_{2} \mathbf{O}$ & - & - & - & - & - & - & bdl & bdl & bdl & - & Bdl & 8.35 & 5.22 & - \\
\hline $\mathrm{TiO}_{2}$ & bdl & bdl & & - & 0.17 & bdl & bdl & bdl & bdl & 0.06 & 0.03 & 0.21 & 0.13 & - \\
\hline $\mathrm{FeO}$ & 9.25 & 9.70 & 14.80 & 24.76 & 21.24 & 16.33 & 2.90 & 3.72 & 2.02 & 2.55 & 2.22 & 3.45 & 5.03 & 0.41 \\
\hline MnO & 0.47 & 0.63 & 0.21 & 0.48 & 0.49 & 0.29 & bdl & 0.12 & bdl & bdl & bdl & bdl & 0.05 & bdl \\
\hline $\mathrm{Cr}_{2} \mathrm{O}_{3}$ & 1.44 & 1.45 & 23.09 & 37.02 & 35.76 & 31.01 & bdl & bdl & bdl & 1.39 & 1.06 & 0.76 & 1.14 & - \\
\hline $\mathrm{Na}_{2} \mathrm{O}$ & - & - & - & - & - & - & bdl & bdl & bdl & bdl & bdl & 0.13 & 0.04 & bdl \\
\hline $\mathrm{NiO}$ & - & - & 0.10 & - & bdl & bdl & bdl & - & bdl & 0.15 & 0.17 & 0.17 & 0.53 & - \\
\hline $\mathrm{Cl}$ & - & - & - & - & - & - & - & 0.06 & 0.06 & - & & & - & 5.57 \\
\hline P2O5 & & & & & & & & & & & & & & 39.57 \\
\hline Sum & 100.27 & 99.73 & 99.80 & 97.85 & 97.86 & 99.35 & 84.94 & 84.43 & 83.83 & 85.42 & 85.60 & 93.45 & 92.57 & 99.21 \\
\hline $\mathbf{S i}$ & 2.99 & 3.01 & 0.00 & 0.00 & 0.00 & 0.00 & 6.23 & 6.13 & 6.38 & 2.92 & 2.85 & 2.87 & 2.67 & \\
\hline $\mathrm{Ti}$ & & & & 0.00 & 0.00 & 0.00 & & & & 0.00 & 0.00 & 0,01 & 0.01 & \\
\hline $\mathrm{Al}(\mathrm{IV})$ & 0.01 & 0.00 & & & & & 1,77 & 1.87 & 1.62 & 2.08 & 2.15 & 2.13 & 2.33 & \\
\hline $\mathrm{Al}(\mathrm{VI})$ & 1.90 & 1.87 & 1.48 & 0.99 & 1.12 & 1.29 & & & & 0.08 & 0.11 & 0.21 & & \\
\hline $\mathrm{Cr}$ & 0.08 & 0.08 & 0.51 & 0.93 & 0.87 & 0.71 & & & & 0.11 & 0.08 & $0_{-}=03$ & 0.106 & \\
\hline $\mathrm{Fe}^{3+}$ & 0.02 & 0.05 & 0.00 & 0.00 & 0.00 & 0.00 & & & & & & & & \\
\hline $\mathrm{Fe}^{2+}$ & 0.53 & 0.54 & 0.34 & 0.66 & 0.55 & 0.40 & 0.04 & 0.05 & 0.03 & 0.20 & 0.18 & 0.21 & 0.30 & 0.06 \\
\hline Mn & 0.03 & 0.04 & 0.00 & 0.01 & 0.01 & 0.01 & & 0.02 & & & & & & \\
\hline Mg & 2.02 & 1.99 & 0.67 & 0.43 & 0.44 & 0.60 & 9.09 & 9.10 & 8.94 & 4.53 & 4.58 & 2.72 & 3.04 & \\
\hline $\mathrm{Ca}$ & 0.41 & 0.44 & & & & & & & & 0.00 & 0.00 & & & 10.18 \\
\hline Cl & & & & & & & & 0.016 & 0.01 & & & & & 1.68 \\
\hline $\mathbf{P}$ & & & & & & & & & & & & & & 5.97 \\
\hline Sum & 8.00 & 8.00 & 3.00 & 3.00 & 3.00 & 3.00 & 15.763 & 15.864 & $15.6 \underline{2} 29$ & 9.95 & 10.00 & 7.90 & 7.93 & 17.90 \\
\hline Mg\# & 0.79 & 0.78 & 0.66 & 0.43 & 0.44 & 0.60 & 0.96 & 0.95 & 0.97 & 0.96 & 0.96 & 0.96 & 0.90 & \\
\hline
\end{tabular}


| Table3. Representative EPMA analyses of carbonate minerals. Values reported in wt. $\% . \mathrm{CO}_{2}$ reported to 100 for elements recalculations.

\begin{tabular}{|c|c|c|c|c|c|c|c|c|c|c|c|c|c|c|c|c|c|}
\hline \multirow{5}{*}{$\begin{array}{l}\text { Sample } \\
\text { Type } \\
\text { Mineral } \\
\text { Comment } \\
\text { n } \\
\end{array}$} & \multirow{2}{*}{\multicolumn{4}{|c|}{$\begin{array}{l}\text { 18LP1 } \\
\text { Coarse } \\
\end{array}$}} & \multicolumn{4}{|c|}{ MOL1-C } & \multicolumn{7}{|l|}{ MM1 } & \multirow{2}{*}{\multicolumn{2}{|c|}{$\begin{array}{l}\text { VM10A } \\
\text { Fine } \\
\end{array}$}} \\
\hline & & & & & & & & & \multicolumn{4}{|l|}{ Fine } & & & & & \\
\hline & \multicolumn{2}{|l|}{ Dol } & \multicolumn{2}{|l|}{ Dol } & \multicolumn{2}{|l|}{ Dol } & \multicolumn{2}{|l|}{ Mgs } & Dol & & Dol & & \multicolumn{2}{|l|}{ Dol } & \multirow{2}{*}{$\begin{array}{c}\text { Dol } \\
\text { In } \\
\text { mag } \\
\end{array}$} & \multicolumn{2}{|l|}{ Dol } \\
\hline & \multicolumn{2}{|l|}{ Vein } & \multicolumn{2}{|l|}{ In opx } & \multicolumn{2}{|c|}{ Vein $\mathrm{w} / \mathrm{mgs}$} & \multicolumn{2}{|l|}{ Vein } & \multicolumn{2}{|c|}{ In liz vein } & \multicolumn{2}{|l|}{ Matrix } & \multicolumn{2}{|l|}{ In spl } & & \multicolumn{2}{|l|}{ Matrix } \\
\hline & 16 & $2 \sigma$ & 2 & $2 \sigma$ & 7 & $2 \sigma$ & 23 & $2 \sigma$ & 11 & $2 \sigma$ & 24 & $2 \sigma$ & 8 & $2 \sigma$ & 1 & 42 & $2 \sigma$ \\
\hline $\mathrm{MgO}$ & 20.65 & 0.26 & 20.79 & 0,09 & 20.48 & 0.16 & 42.45 & 1.61 & 20.36 & 0.45 & 20.30 & 0.27 & 20.06 & 0.35 & 20.58 & 20.29 & 0.15 \\
\hline $\mathrm{CaO}$ & 29.58 & 0.27 & 29.61 & 0,12 & 29.18 & 0.48 & 0.18 & 0.04 & 29.47 & 0.10 & 29.26 & 0.32 & 29.19 & 0.29 & 29.87 & 29.42 & 0.33 \\
\hline $\mathrm{MnO}$ & 0.06 & 0.12 & 0.08 & 0.11 & 0.43 & 0.38 & 0.23 & 0.06 & 0.03 & 0.06 & 0.03 & $0=07$ & 0.02 & 0.05 & 0.27 & 0.04 & 0.00 \\
\hline $\mathrm{FeO}$ & 1.26 & 0.15 & 1.21 & 0.10 & 1.31 & 0.39 & 5.68 & 2.10 & 1.24 & 0.07 & 1.34 & $0_{i}=09$ & 1.44 & 0.06 & 1.96 & 1.47 & 0.01 \\
\hline $\mathrm{SrO}$ & 0.01 & 0.04 & $\underline{\underline{b d} 10.00}$ & 0.00 & 0.09 & 0.12 & $\underline{\mathrm{bd} 10.00}$ & 0.00 & 0.13 & 0.11 & $0_{i ;}, 14$ & $0_{i}=12$ & 0.20 & 0.09 & $\frac{\mathrm{bdl}}{0.00}$ & 0.05 & 0.02 \\
\hline $\mathrm{CO}_{2}$ & 48.44 & 0.27 & 48.33 & 0.22 & 48.51 & 0.39 & 51.46 & 0.71 & 48.76 & 0.34 & 48.92 & 0.35 & 49.11 & 0.41 & 47.32 & 48.73 & 0.12 \\
\hline Sum & 100.00 & - & 100.00 & - & 100.00 & - & 100.00 & - & 100.00 & - & 100.00 & - & 100.00 & - & 100.00 & 100.00 & - \\
\hline Mg & 0.97 & 0.01 & 0.97 & $\theta, 0 \theta$ & 0.96 & 0.01 & 1.85 & 0.05 & 0.96 & 0.01 & 0.96 & 0.01 & 0.96 & 0.01 & 0.95 & 0.96 & 0.01 \\
\hline $\mathrm{Fe}^{2+}$ & 0.03 & 0.00 & 0.03 & 0,00 & 0.03 & 0.01 & 0.14 & 0.05 & 0.03 & 0.00 & 0.04 & 0.00 & 0.04 & 0.00 & 0.05 & 0.04 & 0.00 \\
\hline Mn & $\theta .00$ & $\theta .00$ & $\theta .00$ & $\theta, 0 \theta$ & 0.01 & $\theta .01$ & 0.01 & $\theta .00$ & 0.00 & 0.00 & $\theta .00$ & $\theta, 0 \theta$ & $\theta .0 \theta$ & $\theta .00$ & 0.01 & 0.00 & 0.00 \\
\hline Ea & 1.00 & 0.01 & 0.99 & 0.00 & 0.99 & 0.02 & 0.01 & 0.00 & 1.00 & 0.01 & 1.00 & 0,01 & 1.00 & 0.01 & 0.99 & 1.00 & 0.01 \\
\hline Sr & 0.00 & 0.00 & 0.00 & 0.00 & bdl & & bdl & 0.00 & 0.00 & 0.00 & 0.00 & 0,00 & $\theta, 00$ & 0.00 & 0.00 & 0.00 & 0.00 \\
\hline C & $z .00$ & $\theta .00$ & 2.00 & $\theta .0 \theta$ & 2.00 & $\theta .0 \theta$ & 2.00 & $\theta .00$ & 2.00 & 0.00 & 2.00 & $\theta, 0 \theta$ & 2.00 & $\theta .00$ & 2.00 & 2.00 & $\theta .00$ \\
\hline Fot & 4.00 & - & 4.00 & - & 4.00 & - & 4.00 & - & 4.00 & - & 4.00 & - & 4.00 & - & 4.00 & 4.00 & - \\
\hline $\mathrm{CaCO}_{3}$ & 49.84 & 0.46 & 49.73 & 0.01 & 49.38 & 0.86 & 0.28 & 0.06 & 50.07 & 0.54 & 49.89 & 0.51 & 50.03 & 0.58 & 49.58 & 49.99 & 0.53 \\
\hline $\mathrm{MgCO}_{3}$ & 48.41 & 0.47 & 48.58 & 0.01 & 48.23 & 0.48 & 92.47 & 2.73 & 48.12 & 0.64 & 48.16 & 0.54 & 47.83 & 0.54 & 47.53 & 47.97 & 0.57 \\
\hline $\mathrm{MnCO}_{3}$ & 0.08 & 0.15 & 0.10 & 0.14 & 0.58 & 0.50 & 0.28 & 0.08 & 0.04 & 0.08 & 0.05 & 0.09 & 0.03 & 0.07 & $0=35$ & 0.05 & 0.00 \\
\hline $\mathrm{FeCO}_{3}$ & 1.66 & 0.20 & 1.58 & 0.14 & 1.73 & 0.51 & 6.96 & 2.66 & 1.64 & 0.10 & 1.78 & 0.11 & 1.92 & 0.08 & 2.54 & 1.95 & 0.02 \\
\hline $\mathrm{SrCO}_{3}$ & 0.01 & 0.04 & 0.00 & 0.00 & 0.08 & 0.11 & 0.00 & 0.00 & 0.12 & 0.10 & 0.12 & 0.11 & 0.18 & 0.08 & 0.00 & 0.05 & 0.03 \\
\hline $\mathrm{Mg} /(\mathrm{Mg}+\mathrm{Ca})$ & 0.49 & 0.00 & 0.49 & 0.00 & 0.49 & 0.01 & 1.00 & 0.00 & 0.49 & 0.01 & 0.49 & 0.01 & 0.49 & 0.01 & 0.49 & 0.49 & 0.01 \\
\hline
\end{tabular}

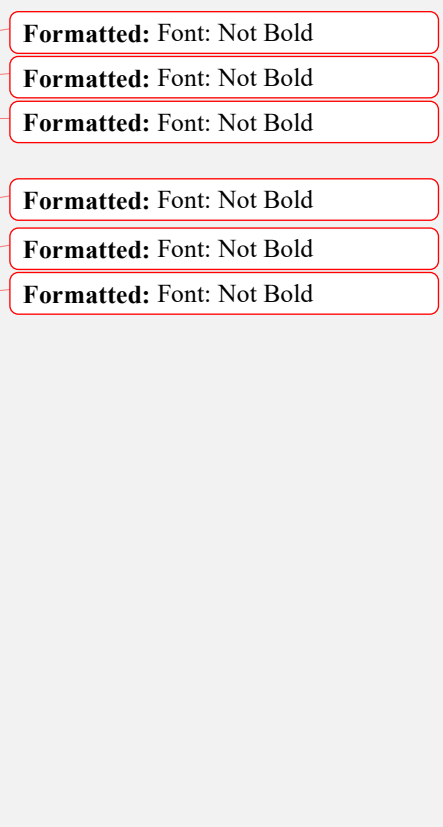

$b d l$ Below detection limit, w/cal+brc associated with cal+brc intergrowths 
Table3. Continued.

\begin{tabular}{|c|c|c|c|c|c|c|c|c|c|c|c|c|c|c|c|c|}
\hline \multirow{5}{*}{$\begin{array}{l}\text { Sample } \\
\text { Type } \\
\text { Mineral } \\
\text { Comment } \\
\text { n } \\
\end{array}$} & \multicolumn{6}{|l|}{ KL1-A } & \multicolumn{6}{|c|}{ KL2.4-2b } & \multirow{2}{*}{\multicolumn{2}{|c|}{$\begin{array}{l}\text { KL2.4-3 } \\
\text { Porph-fine }\end{array}$}} & \multirow{2}{*}{\multicolumn{2}{|c|}{$\begin{array}{l}\text { KL1.6 } \\
\text { fine }\end{array}$}} \\
\hline & \multicolumn{2}{|l|}{ Fine } & & & & & \multicolumn{6}{|c|}{ Porph-fine } & & & & \\
\hline & \multicolumn{2}{|l|}{ Dol } & \multicolumn{2}{|l|}{ Dol } & \multicolumn{2}{|l|}{$\mathrm{Cal}$} & \multicolumn{2}{|l|}{ Dol } & \multicolumn{2}{|l|}{ Dol } & \multicolumn{2}{|l|}{$\mathrm{Cal}$} & \multicolumn{2}{|l|}{ Cal } & \multicolumn{2}{|l|}{ Dol } \\
\hline & \multicolumn{2}{|l|}{ Matrix } & \multicolumn{2}{|c|}{$\mathrm{w} / \mathrm{cal}+\mathrm{brc}$} & \multicolumn{2}{|l|}{ cal+brc } & \multicolumn{2}{|l|}{ In spl } & \multicolumn{2}{|c|}{ In spl, w/cal+brc } & \multicolumn{2}{|c|}{ cal+brc pol.ag. } & \multicolumn{2}{|c|}{ In spl (in grt) } & \multicolumn{2}{|l|}{ vein } \\
\hline & 22 & $2 \sigma$ & 6 & $2 \sigma$ & 4 & $2 \sigma$ & 4 & $2 \sigma$ & 9 & $2 \sigma$ & 2 & $2 \sigma$ & 2 & $2 \sigma$ & 30 & $2 \sigma$ \\
\hline \multicolumn{17}{|l|}{$\mathrm{Wt} \%$} \\
\hline $\mathrm{MgO}$ & 20.51 & 0.23 & 20.05 & 0.08 & 0.33 & 0.30 & 20.01 & 0.30 & 20.13 & 1.20 & 0.38 & 0.11 & 0.00 & 0.00 & 19.58 & 0.44 \\
\hline $\mathrm{CaO}$ & 29.30 & 0.20 & 28.97 & 0.22 & 54.33 & 0.37 & 29.17 & 0.16 & 29.82 & 1.40 & 49.48 & 0.43 & 57.19 & 0.08 & 29.74 & 0.32 \\
\hline $\mathrm{MnO}$ & 0.11 & 0.27 & 0.02 & 0.06 & $0.00 \mathrm{bdl}$ & 0.00 & 0.05 & 0.07 & 0.02 & 0.04 & 0.03 & 0.04 & $\underline{\mathrm{bd} 10.00}$ & 0.00 & 0.04 & 0.09 \\
\hline $\mathrm{FeO}$ & 1.52 & 0.12 & 1.63 & 0.06 & $\underline{\text { bdl } 10.00}$ & 0.00 & 1.60 & 0.08 & 1.75 & 0.46 & 1.41 & 0.33 & 0.41 & 0.15 & 1.43 & 0.18 \\
\hline $\mathrm{SrO}$ & 0.03 & 0.07 & $\underline{\text { bdl } 10.00}$ & 0.00 & 0.22 & 0.05 & 0.09 & 0.10 & 0.05 & 0.09 & 0.16 & 0.22 & $\underline{\text { bdl } \theta .00}$ & 0.00 & 0.02 & 0.05 \\
\hline $\mathrm{CO}_{2}$ & 48.53 & 0.26 & 49.33 & 0.22 & 45.12 & 0.09 & 49.08 & 0.27 & 48.24 & 2.22 & 48.53 & 0.15 & 42.40 & 0.23 & 49.20 & 0.50 \\
\hline Sum & 100.00 & - & 100.00 & - & 100.00 & - & 100.00 & - & 100.00 & - & 100.00 & - & 100.00 & - & 100.00 & - \\
\hline $\mathrm{Mg}$ & 0.97 & 0.01 & 0.96 & 0.01 & 0.02 & 0.02 & 0,95 & 0.01 & 0.95 & 0.03 & 0.02 & 0.01 & 0.00 & 0.00 & 1.09 & 0.54 \\
\hline $\mathrm{Fe}^{2+}$ & 0.04 & $\theta .00$ & 0.04 & $\theta .00$ & $\theta .00$ & $\theta .00$ & $\theta, 04$ & 0.00 & 0.05 & 0.01 & $\theta .04$ & 0.01 & 0.01 & $\theta .00$ & 0.04 & 0.02 \\
\hline Mn & 0.00 & 0.01 & 0.00 & 0.00 & 0.00 & 0.00 & 0,00 & 0.00 & 0.00 & 0.00 & 0.00 & 0.00 & 0.00 & 0.00 & 0.00 & 0.00 \\
\hline $\mathrm{Ca}$ & 0.99 & 0.00 & 1.00 & 0.00 & 1.98 & 0.02 & 100 & 0.01 & 1.01 & 0.04 & 1.93 & 0.01 & 1.84 & 0.02 & 1.18 & 0.55 \\
\hline $\mathbf{S r}$ & 0.00 & $\theta .00$ & 0.00 & 0.00 & 0.00 & 0.00 & 0.00 & 0.00 & 0.00 & 0,00 & $\theta .00$ & 0.00 & 0.00 & $\theta .00$ & 0.00 & 0.00 \\
\hline C & 2.00 & $\theta .00$ & 2.00 & $\theta .00$ & 2.00 & $\theta .00$ & 2.00 & $\theta .00$ & 2.00 & $\theta .00$ & $z .0 \theta$ & $\theta .00$ & 2.07 & $\theta .01$ & 1.84 & 0.55 \\
\hline Fot & 4.00 & - & 4.00 & - & 4.00 & - & 4.00 & - & 4.00 & - & 4.00 & - & 3.93 & - & 4.16 & - \\
\hline $\mathrm{CaCO}_{3}$ & 49.55 & 0.22 & 49.82 & 0.25 & 98.93 & 0.77 & 49.99 & 0.45 & 50.36 & 1.77 & 96.59 & 0.66 & 99.44 & 0.20 & 51.15 & 0.61 \\
\hline $\mathrm{MgCO}_{3}$ & 48.27 & 0.39 & 47.96 & 0.27 & 0.85 & 0.76 & 47.72 & 0.46 & 47.27 & 1.50 & 1.04 & 0.31 & 000 & 0.00 & 46.86 & 0.68 \\
\hline $\mathrm{MnCO}_{3}$ & 0.15 & 0.37 & 0.03 & 0.08 & 0.00 & 0.00 & 0.07 & 0.10 & 0.02 & 0.05 & 0.04 & 0.06 & 000 & 0.00 & 0.05 & 0.12 \\
\hline $\mathrm{FeCO}_{3}$ & 2.00 & 0.15 & 2.18 & 0.08 & 0.00 & 0.00 & 2.14 & 0.10 & 2.29 & 0.54 & 2.15 & 0.51 & 0.56 & 0.20 & 1.92 & 0.25 \\
\hline $\mathrm{SrCO}_{3}$ & 0.02 & 0.06 & 0.00 & 0.00 & 0.22 & 0.05 & 0.08 & 0.10 & 0.05 & 0.08 & 0.16 & 0.23 & 0.00 & 0.00 & 0.02 & 0.05 \\
\hline $\mathrm{Mg} /(\mathbf{M g}+\mathrm{Ca})$ & 0.49 & 0.00 & 0.49 & 0.00 & 0.01 & 0.01 & 0.49 & 0.00 & 0.48 & 0.02 & 0.01 & 0.00 & 0.00 & 0.00 & 0.48 & 0.01 \\
\hline
\end{tabular}

Formatted: Font: Not Bold

Formatted: Font: Not Bold

Formatted: Font: Not Bold

Formatted: Font: Not Bold

Formatted: Font: Not Bold

Formatted: Font: Not Bold

Formatted: Font: Not Bold

Formatted: Font: Not Bold 
| Table4. ${ }^{87} \mathrm{Sr} /{ }^{86} \mathrm{Sr}$ and ${ }^{87} \mathrm{Rb} /{ }^{86} \mathrm{Sr}$ isotope ratio measured by LA-MC-ICP-MS for selected carbonates in Ulten Zone peridotites.

\begin{tabular}{|c|c|c|c|c|c|c|c|}
\hline $\begin{array}{l}\text { Sample } \\
\text { and } \\
\text { mineral }\end{array}$ & $\#$ & Microstructure & ${ }^{88} \mathrm{Sr}(\mathrm{V})$ & ${ }^{87} \mathrm{Rb} /{ }^{86} \mathrm{Sr}$ & ${ }^{87} \mathrm{Sr} /{ }^{86} \mathrm{Sr}$ & $2 \mathrm{se}$ & $\begin{array}{r}\text { Spot } \\
\text { Size } \\
(\mu \mathrm{m})\end{array}$ \\
\hline \multicolumn{8}{|l|}{ MOL1-C } \\
\hline Dolomite & 1 & Vein & $\underline{0.8}$ & $\leq 0.0001$ & 0.71189 & 0.00030 & 65 \\
\hline Dolomite & 2 & Vein & $\underline{1.3}$ & $\underline{0.0002}$ & 0.71178 & 0.00023 & 65 \\
\hline \multicolumn{8}{|l|}{ 18LP1 } \\
\hline Dolomite & 9 & Vein & $\underline{1.4}$ & $\leq 0.0001$ & 0.70830 & 0.00015 & 100 \\
\hline Dolomite & 10 & Vein & $\underline{1.6}$ & $<0.0001$ & 0.70702 & 0.00017 & 100 \\
\hline Dolomite & 11 & Vein & $\underline{1.3}$ & $\leq 0.0001$ & 0.70694 & 0.00016 & 100 \\
\hline Dolomite & 8 & Vein & 2.4 & $\overline{<0.0001}$ & 0.70392 & 0.00013 & 90 \\
\hline Dolomite & 7 & Vein & 1.2 & $\overline{<0.0001}$ & 0.70571 & 0.00017 & 90 \\
\hline Dolomite & 6 & Vein & $\underline{0.8}$ & 0.0001 & 0.70541 & 0.00026 & 65 \\
\hline Dolomite & 5 米 & Vein & $\underline{3.0}$ & $\overline{<0.0001}$ & 0.70360 & 0.00007 & 65 \\
\hline Dolomite & 4 & Vein & 1.2 & $\underline{0.0003}$ & 0.70680 & 0.00013 & 65 \\
\hline Dolomite & 3 * & Vein & 1.5 & 0.0001 & 0.70658 & 0.00019 & 100 \\
\hline Dolomite & 12 & Vein & $\underline{0.5}$ & $\leq 0.0001$ & 0.70531 & 0.00031 & 100 \\
\hline Dolomite & 13 & Vein & $\underline{0.7}$ & $\underline{0.0001}$ & 0.70509 & 0.00030 & 100 \\
\hline Dolomite & $14 \underline{*}^{+}$ & Vein & $\underline{1.6}$ & $\overline{<0.0001}$ & 0.70636 & 0.00012 & 100 \\
\hline \multicolumn{8}{|l|}{ VM10A } \\
\hline Dolomite & 23 * & Matrix & $\underline{3.4}$ & $\leq 0.0001$ & 0.70521 & 0.00011 & 65 \\
\hline Dolomite & 22 * & Matrix & 1.2 & $\leq 0.0001$ & 0.70519 & 0.00035 & 65 \\
\hline Dolomite & $20 *$ & Matrix & 3.4 & $\leq 0.0001$ & 0.70539 & 0.00006 & 65 \\
\hline Dolomite & $21 *$ & Matrix & $\underline{1.6}$ & $<0.0001$ & 0.70529 & 0.00017 & 55 \\
\hline Dolomite & $19^{+}$ & In zircon & $\underline{1.3}$ & $\underline{0.0011}$ & 0.70597 & 0.00007 & 55 \\
\hline \multicolumn{8}{|l|}{ KL1-A } \\
\hline Dolomite & 15 & Matrix & $\underline{1.2}$ & $\underline{0.0004}$ & 0.70671 & 0.00021 & 65 \\
\hline Calcite & 16 & In cal+brc & 2.4 & $\leq 0.0001$ & 0.70707 & 0.00021 & 65 \\
\hline Calcite & 17 & In cal+brc & $\underline{08}$ & $\leq 0.0001$ & 0.70709 & 0.00023 & 65 \\
\hline Calcite & 18 & In cal+brc & $\underline{1.1}$ & $\overline{<0.0001}$ & 0.70741 & 0.00009 & 65 \\
\hline \multicolumn{8}{|l|}{ MM1 } \\
\hline Dolomite & 24 & Matrix & $\underline{4.7}$ & $\leq 0.0001$ & 0.70486 & 0.00007 & 65 \\
\hline Dolomite & $25 *$ & Matrix & $\underline{4.4}$ & $\overline{<0.0001}$ & 0.70489 & 0.00005 & 65 \\
\hline Dolomite & 26 & Matrix & $\underline{4.6}$ & $\leq 0.0001$ & 0.70478 & 0.00005 & 65 \\
\hline Dolomite & 27 & Matrix & $\underline{4.5}$ & $\overline{<0.0001}$ & 0.70490 & 0.00008 & 65 \\
\hline Dolomite & 28 & Matrix & $\underline{2.4}$ & $\leq 0.0001$ & 0.70502 & 0.00012 & 65 \\
\hline Dolomite & 29 & Matrix & 3.3 & $\overline{\leq 0.0001}$ & 0.70495 & 0.00008 & 65 \\
\hline Dolomite & 30 & Matrix & $\underline{3.8}$ & $\underline{0.0002}$ & 0.70491 & 0.00006 & 65 \\
\hline Dolomite & 31 & Matrix & $\underline{2.0}$ & 0.0005 & 0.70478 & 0.00012 & 65 \\
\hline Dolomite & $32 \underline{*}$ & Matrix & 2.7 & $\overline{0.0004}$ & 0.70484 & 0.00008 & 65 \\
\hline Dolomite & 33 & Matrix & $\underline{4.8}$ & $\leq 0.0001$ & 0.70481 & 0.00005 & 65 \\
\hline Dolomite & $34 *$ & Matrix & $\underline{1.3}$ & $<0.0001$ & 0.70479 & 0.00022 & 65 \\
\hline Dolomite & 35 & Matrix & 4.2 & $\overline{<0.0001}$ & 0.70477 & 0.00005 & 65 \\
\hline Dolomite & 36 & Matrix & 2.9 & $\underline{0.0005}$ & 0.70484 & 0.00007 & 65 \\
\hline Dolomite & 37 米 & Matrix & $\underline{1.7}$ & $\underline{0.0007}$ & 0.70513 & 0.00024 & 65 \\
\hline Dolomite & 38 & Matrix & $\underline{1.5}$ & $\underline{0.0004}$ & 0.70480 & 0.00019 & 65 \\
\hline Dolomite & 39 & Matrix & $\underline{3.6}$ & $\overline{\leq 0.0001}$ & 0.70479 & 0.00006 & 65 \\
\hline
\end{tabular}

Table4. ${ }^{87} \mathrm{Sr}{ }^{86} \mathrm{Sr}$ isotope ratio measured with LA-MC-ICP-MS for selected carbonates in Ulten

Zone peridotites. $(+)$ Aanalyses were collected along lines using the same spot size for spot

analyses (i.e. $55 \mu \mathrm{m})$.

.Sr (ppm) concentrations were recalculated from EPMA analyses. b.d.l. is below detection limit.

For (*) samples, Sr and Rb concentrations were analyzed in LA-ICP-MS. Rb concentration is below detection limit if $<0.0046 \mathrm{ppm}$. n.a. not analysed; cal $+b r c$ calcite + brucite intergrowths. 
Table I. Major elements compositions (wt\%) of olivine. Formula based on 4 oxyc

\begin{tabular}{|c|c|c|c|c|c|}
\hline Anions & 4 & 4 & 4 & 4 & 4 \\
\hline Cations & 3 & 3 & 3 & 3 & 3 \\
\hline Rock type & $\mathrm{F}$ & $\mathrm{F}$ & $\mathrm{F}$ & $\mathrm{F}$ & $\mathrm{F}$ \\
\hline Sample & MM1 & MM1 & MM1 & MM1 & MM1 \\
\hline Text. Pos. & $\mathrm{m}$ & $\mathrm{m}$ & $\mathrm{m}$ & $\mathrm{m}$ & $\mathrm{m}$ \\
\hline Elemento & MM1_ol1 & MM1_ol2 & MM1_ol3 & MM1_ol5 & MM1_ol6 \\
\hline $\mathrm{MgO}$ & 50.1 & 49.24 & 49.54 & 49.89 & 49.92 \\
\hline $\mathrm{Al}_{2} \mathrm{O}_{3}$ & bdl & bdl & bdl & bdl & bdl \\
\hline $\mathrm{SiO}_{2}$ & 40.85 & 40.53 & 40.66 & 40.56 & 40.53 \\
\hline TiO2 & bdl & bdl & bdl & bdl & bdl \\
\hline $\mathrm{Cr}_{2} \mathrm{O}_{3}$ & bdl & bdl & bdl & bdl & bdl \\
\hline $\mathrm{MnO}$ & 0.16 & 0.12 & 0.12 & 0.12 & 0.18 \\
\hline $\mathrm{FeO}$ & 9.54 & 9.65 & 9.52 & 9.42 & 9.30 \\
\hline $\mathrm{NiO}$ & 0.36 & 0.42 & 0.34 & 0.35 & 0.34 \\
\hline Sum & 101.01 & 100.02 & 100.18 & 100.34 & 100.26 \\
\hline $\mathrm{Si}$ & 0.99 & 0.99 & 0.99 & 0.99 & 0.99 \\
\hline \multicolumn{6}{|l|}{$\mathrm{Ti}$} \\
\hline \multicolumn{6}{|l|}{$\mathrm{Al}$} \\
\hline \multicolumn{6}{|l|}{$\mathrm{Cr}$} \\
\hline $\mathrm{Fe}^{2+}$ & 0.19 & 0.20 & 0.19 & 0.19 & 0.19 \\
\hline $\mathrm{Ni}$ & 0.01 & 0.01 & 0.01 & 0.01 & 0.01 \\
\hline $\mathrm{Mn}$ & 0.00 & 0.00 & 0.00 & 0.00 & 0.00 \\
\hline $\mathrm{Mg}$ & 1.81 & 1.80 & 1.81 & 1.82 & 1.82 \\
\hline Sum & 3.01 & 3.01 & 3.01 & 3.01 & 3.01 \\
\hline Fo & 90.20 & 89.98 & 90.16 & 90.31 & 90.38 \\
\hline $\mathrm{Fa}$ & 9.64 & 9.90 & 9.72 & 9.57 & 9.44 \\
\hline Teph & 0.16 & 0.12 & 0.12 & 0.12 & 0.18 \\
\hline $\mathrm{N}^{\circ} \mathrm{Mg}$ & 90.35 & 90.09 & 90.16 & 90.42 & 90.54 \\
\hline
\end{tabular}

F: fine-grained; C: coarse-grained; P: porphyroclastic texture; m: matrix . $\mathrm{N}^{\circ} \mathrm{Mg}, \mathrm{N}$ 